\title{
Prospective Teachers' Views Regarding Pedagogical Courses, Field Knowledge Courses and Willingness to Serve as a Teacher
}

\author{
Şenol BEŞOLUK * \\ Mehmet Barış HORZUM **
}

\begin{abstract}
In this research, where the aim is to determine prospective teachers' views concerning pedagogical courses, field knowledge courses and their willingness to perform the teaching profession, 403 senior students attending the Faculty of Education and Technical Education in Sakarya University were chosen as a sample. The data were collected via a survey of demographic questions and 3 open-ended questions developed by the researchers, and then were analyzed. The analyses demonstrated that students in faculty of education compared to technical education, students who have chosen their departments willingly compared to those who not and students attending departments with high proportion of being employed as teachers compared to those attending the departments with lower proportion of being employed, considered pedagogical courses more important and indicated higher willingness to serve as a teacher. Of the students, $46.1 \%$ stated that all of the field courses were important, $40.7 \%$ stated that most of those courses were important but some of them were unnecessary, whereas $8.9 \%$ stated that most of those courses were unnecessary. It was found in the research that students mostly stressed the employment problem therefore the quota for student acceptance into educational faculties should be established on the basis of needs and in a realistic way.
\end{abstract}

Keywords: Prospective teachers, pedagogical courses, field courses, willingness to serve as a teacher.

\footnotetext{
* Assist. Prof. Dr. Sakarya University, Education Faculty, Department of Science and Technology, Hendek, Sakarya, Turkey. E-mail: sbesoluk@sakarya.edu.tr

** Assist. Prof. Dr. Sakarya University, Education Faculty, Department of Computer Education and Instructional Technology, Hendek / Sakarya.E-mail: mhorzum@sakarya.edu.tr
} 


\section{INTRODUCTION}

The fact that teachers are people who present information, who teach students ways of reaching information, who guide them, who set role models for them and who prepare them for the future are indicators of a teacher's important qualities (Çelikkaya, 2006). That teachers are the people who directly influence the quality of education is the major reason for considering teacher training as one of the most important issues of a country (Gökçe, 2001).

Teachers have been only trained in various educational faculties since 1982 (YÖK, 2007). Various factors such as the facilities of the teacher training institution, the properties of the teaching staff, curriculum, the quality of education provided, incoming students' motivation and interests, their levels of knowledge and skills are influential in prospective teachers' properties significantly (Bulut and Doğar, 2006; Çelikkaya, 2006).

The sufficiency of facilities such as classrooms, technological infrastructure, social facilities and laboratories that the teacher training faculty has, is extremely important in teacher training. Besides sufficiency or insufficiency of those facilities, there are qualitative as well as quantitative problems related to academic stuff. Some of those problems are, academic proficiency, suitability of academic working environment, the proportion of distribution of career stages, openness to change and development, experience, academic publications, the number of students per lecturer, class load out of the field and work load (ÖYKSÇ, 2005: Mart).

The qualities of students attending the teacher training faculties, their motivation in particular, vary according to several factors. Universities have no possibilities of preference on students' admission; instead students choose a university or a department on the basis of scores they obtained in the Student Selection Examination. Factors such as the social status that the profession provides, opportunities to get a job, economic benefits, and psychological satisfaction affect the students' department/program choice (Aksu, Daloğlu, Yıldırım, Kiraz and Demir, 2008) and therefore the quality of education received will be affected. The students who have chosen their department at university on purpose and consciously have attitudes and thoughts for the courses that differs from those students who have entered their department just because their scores are sufficient or due to unconscious choice.

The rate of general unemployment announced by Turkish Association of Statistics is $13.4 \%$ whereas the rate of unemployment for university graduates is $14.2 \%$ (TUIK, 2009). On examining the rate of employment by the Ministry of Education- by whom great majority of teachers are employed- for the 6 years (2004-2009), it is found that the rate is $61 \%$ for 
information technologies teachers, 58\% for psychological counseling and guidance teachers, $29 \%$ for elementary school teachers, $15 \%$ for science and technology teachers and pre-school education teachers, $9 \%$ for social studies teachers, $7 \%$ for electronics teachers, and less than $1 \%$ for construction teachers and automotive teachers. The rate of employment is one of the factors directly influencing students' views, motivation, anxiety levels and attitudes (Kızılçaoğlu, 2003). Therefore, it is predicted that rates of employment varying on the basis of departments will cause differences in students' views.

The aim of the study was to describe and discuss views of senior students of Educational Faculty and Technical Education Faculty about field knowledge, pedagogical knowledge and practice teaching courses as well as their willingness to serve as a teacher.

\section{METHOD}

This research employs the relational survey method. Relational survey methods are the studies which aim to determine the changes between two and more variables occurring at the same time (Karasar, 1995).

The study group was composed of 403 senior university students of whom 303 attended the Educational Faculty and 100 attended the Technical Education Faculty of Sakarya University in the Spring Semester of the 20082009 academic year.

Demographic section was used in the research to obtain information on gender, departments and faculties, and on whether or not the faculty or the department was chosen willingly in addition to demographic section a survey of three open-ended questions was used to obtain students' views. The responses given by students to the questions were written on paper, the similar answers were grouped and the same number was assigned to similar answers. The data were expressed numerically and were shown in percentages and frequencies. Chi square statistics was applied to the suitable data.

\section{FINDINGS, INTERPRETATIONS AND DISCUSSION}

Initially, the students were asked the question "do you consider pedagogical formation courses necessary and important? Explain with your reasons" and the received answers were analyzed in three separate parts.

Of the participants, $90.6 \%$ stated that they considered pedagogical formation courses necessary and important, $6.9 \%$ stated that they did not consider those courses necessary and important, $2.5 \%$ said they were 
undecided. This is a finding which is compatible with those obtained by Deniz (1998), Ekici (2008), Kılıç (2007), and Semerci (2004). Due to the fact that the research was conducted in faculties training teachers, it had been predicted that teaching courses would be considered necessary and important.

The students who were aware of the necessity and the importance of pedagogical formation courses stated different explanations: those courses would be useful in teaching profession, in the KPSS (Public Personnel Selection Exam) exam, in daily life situations and in both teaching profession and daily life. The students who did not consider those courses necessary or important, on the other hand, pointed out that they were not going to be employed as teachers and that they did not consider those courses necessary since they were not taught effectively. However, the students who believed those courses were necessary stressed the existences of the problems stemming from the courses, lecturers, students and the system. Similar problems are also available in the "ÖYKSÇ (2005, Mart)", and in the research conducted by Deniz (1998) and Nartgün (2008).

Female students found pedagogical formation courses necessary and important at a significantly higher level than male students. The studies performed by Demirci and Soran (2001), Saracoğlu (1991), Tanriöğen (1997) showed that girls displayed more positive attitudes towards the profession but the studies performed by Bulut and Doğar (2006), Çapa and Çil (2000), Erden (1995), Gürbüz and Genç (2004), and Öztürk, Doğan and Koç (1995) concluded that there were no differences between the genders.

It was found that Educational Faculty students considered pedagogical formation courses more important and more necessary than Technical Education Faculty students did. This is a finding similar to those obtained by Akpınar and Özer (2003), Öztürk, Doğan and Koç (2005). It was also found that the students who willingly chose their department considered those courses more important and more necessary than the students who did not willingly choose their department. This is compatible with the findings obtained by Tanrı̈ğen (1997). Besides students attending departments with high rates of employment as teachers considered the courses more important and more necessary than those attending departments with low rate of employment. Karasar (1981) also explains the factors affecting the prestige of a program in a similar way (as cited in Akpınar and Özer, 2003).

When the participating students were asked for their views concerning the courses in their field, $46.1 \%$ stated that all the courses in their field were necessary and important, $40.7 \%$ stated majority of them were necessary and some were unnecessary, $8.9 \%$ stated that a great majority of them were 
unnecessary or there were too many courses and therefore they could not sufficiently benefit from them.

The students were also asked the question "are you planning to work as a teacher? Explain your answer with reasons" $69 \%$ of the students stated their willingness of working as a teacher, $17.4 \%$ said that they can work as a teacher if they are appointed, $2.2 \%$ said that although they wish to be a teacher the appointment as a teacher is difficult, and $11.4 \%$ said that they were not willing to serve as a teacher. It was found that $88.6 \%$ in total were wishing to working as a teacher- which is a high percentage. A similar result was also available in Aksu, Daloğlu, Y1ldırım, Kiraz and Demir (2008); in Gürcan and Deniz (2003); in Öztürk, Doğan and Koç (2005).

The statistics made it clear that a considerable number of Technical Education Faculty students did not wish to be teachers and that those who wished had little chance of being appointed. In this case, the "education" part of the name of technical education has lost its meaning. The findings of this current study and of similar research studies demonstrate the need for a modification in technical education faculties. The structure, functions, program and name of those faculties were changed in the year 2009. We believe that it will be beneficial to conduct studies which will facilitate monitoring the new situation.

In conclusion, the problem most frequently emphasized by the students was the Public Personnel Selection Test (KPSS) and the problem of employment. Those problems caused high level of anxiety in prospective teachers. The anxiety, in turn, is reflected into the process of education in a negative way. Because education received especially by educational faculty students is directed to teaching profession, those students' job expectation is also focused on the teaching profession. Therefore, low rate of employment as teachers in most of the departments leads to an increase in anxiety levels and a decrease in performance. For the solution of that problem, it would be more beneficial to determine realistically the need for teachers and establish the number and quota of educational faculties accordingly which will result in training more qualified teachers and effective use of resources. 


\title{
Öğretmen Adaylarının Meslek Bilgisi, Alan Bilgisi Dersleri ve Öğretmen Olma İsteğine İliş̧kin Görüşleri
}

\author{
Şenol BEŞOLUK* ${ }^{*}$ Mehmet Barış HORZUM ${ }^{* *}$
}

\begin{abstract}
ÖZ. Öğretmen adaylarının meslek bilgisi ve alan bilgisi derslerine yönelik görüşleri ile öğretmenlik yapma istekliliklerinin belirlenmesinin amaçlandığı bu araştırmada Sakarya Üniversitesi Eğitim ve Teknik Eğitim fakültelerinde okuyan 403 son sınıf öğrencisi çalışma grubu olarak seçilmiştir. Demografik sorular ve araştırmacılar tarafından geliştirilen 3 açık uçlu sorudan oluşan anketin uygulanması ile veriler toplanmış ve analiz edilmiştir. Analiz sonucunda eğitim fakültesi öğrencileri, teknik eğitim fakültesi öğrencilerine göre; okuduğu bölümü isteyerek tercih eden öğrencilerin, istemeden tercih edenlere göre; atanma oranları yüksek olan bölümlerde okuyanların, atanma oranı düşük olan bölümlerde okuyanlara göre pedagojik formasyon derslerini daha fazla önemli gördükleri ve aynı zamanda öğretmen olma isteklerinin daha fazla olduğu bulunmuştur. Öğrencilerin \%46's1 alan derslerinin tamamının önemli olduğunu, \%40.7'si alan derslerinin büyük bir bölümünün gerekli, bazı derslerin gereksiz olduğunu, \%8.9'u ise derslerin çok büyük kısmının gereksiz olduğunu ifade etmiştir. Araştırmada öğrencilerin en fazla istihdam problemini vurguladıkları görülmüş olup eğitim fakültesi kontenjanlarının ihtiyaçlar doğrultusunda ve gerçekçi olarak planlanması önerilmektedir.
\end{abstract}

Anahtar Sözcükler: Öğretmen adayları, eğitim dersleri, alan dersleri, öğretmen olma isteği.

\footnotetext{
* Yrd. Doç. Dr. Sakarya Üniversitesi Eğitim Fakültesi, Fen ve Teknoloji Eğitimi Bölümü Hendek, Sakarya, Türkiye. E-posta: sbesoluk@sakarya.edu.tr

** Yrd. Doç. Dr. Sakarya Üniversitesi, Eğitim Fakültesi, BÖTE Bölümü, Hendek Kampüsü, 54300 Hendek /Sakarya.E-posta: mhorzum@sakarya.edu.tr
} 


\section{GíRiş}

Nitelikli insan yetiştirmek ülkelerin ve eğitim kurumlarının en önemli amaçlarından biridir. Çağın sahip olduğu bilimsel ve teknolojik seviye, üretim ve tüketim ilişkileri gibi unsurlar ihtiyaç duyulan insan niteliklerini belirlemektedir. Günümüzde bilgi ve teknolojinin yoğun olduğu ortamlarda insanlar bilgiye ulaşabilen, bilgiyi kullanabilen, yeni bilgileri üretebilen ve güncel teknolojileri etkin kullanabilen kişiler olmalıdır. İnsan yetiştirmenin önemli unsurlarından biri olan eğitim kurumlarında bu işi yürüten öğretmenlerdir. Öğretmenlerin öğrencilerine bilgiyi sunan, bilgiye ulaşma yollarını öğreten, rehberlik yapan, rol model olan, onları yönlendiren ve geleceğe hazırlayan uzman kişiler olması önemli nitelik göstergeleridir (Çelikkaya, 2006). Öğretmenlerin, eğitimin niteliğini doğrudan etkileyen kişiler olması, öğretmen yetiştirmenin bir ülkenin en önemli konularından biri olarak görülmesinin temel nedenidir (Gökçe, 2001).

Öğretmen yetiştirilirken, öğretmenlerin sahip olması gereken bilgi ve beceriler tarihin farklı dönemlerinde farklı niteliklerde olduğu görülmektedir (Archambault ve Crippen, 2009). Öğretmenlerin sahip olması gereken bilgi ve becerilerde öncelikle içerik bilgisine odaklanılmıştır (Shulman, 1986). İçerik bilgisinde öğretmenlerin pedagojik bilgileri göz ardı edilerek alan uzmanlıklarının ön plana çıkarıldığ 1 görülmektedir. Daha sonra öğretmenlerin içerik bilgilerine meslek bilgilerini ifade eden pedagojik bilgi eklenmiştir. 1980'li yılların ortalarına gelindiğine öğretmenlere sadece alan ve pedagoji bilgisinin ayrı ayrı öğretilmesinin yeterli olmadığı fikri benimsenmeye başlamıştır. Burada iyi bir öğretimin oluşabilmesinin alan ve pedagoji bilgisini birleştirmeyi gerektirdiği vurgulanmaktadır. Shulman'ın 1987 yılındaki çalışmasında içerik bilgisine pedagojik bilginin eklenmesiyle oluşan pedagojik içerik bilgisi, öğretmenlerin sahip olması gereken bilgilerin tümleşik yapısı oluşturulmuştur. $\mathrm{Bu}$ yapıda öğretmenlerin içerik ve pedagojik bilgilerinin etkileşimini içeren bir beceri ortaya koyulmuştur. Shulman bu yapılanmayı pedagojik içerik bilgisi olarak ifade etmektedir. Pedagojik içerik bilgisi, farklı alanlarda farklı içerik türlerinde farklı yöntem ve tekniklerin kullanılması gerektiğini temel alan bir yapılanmadır (Shulman, 1987). Günümüzde bu yapılara teknoloji bilgisi de eklenmektedir. Tarihsel gelişimde Shulman tarafından önerilen pedagojik içerik bilgisi yapılanması Şekil 1'de yer almaktadır. 


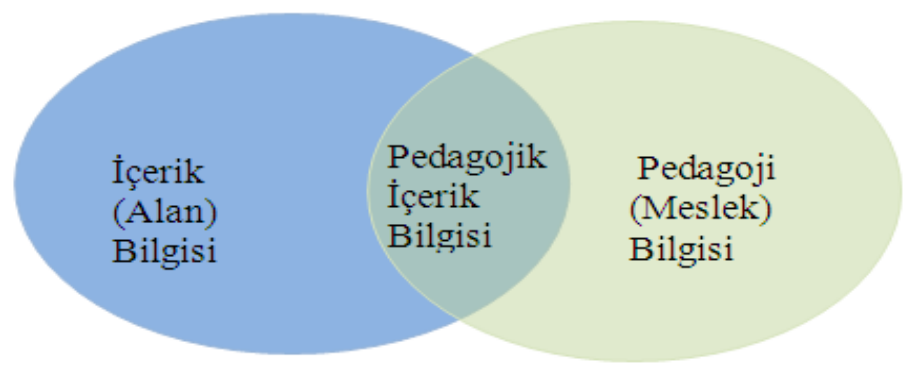

Şekil 1. Pedagojik ve Iç̧erik Bilgisi Etkileşimi

$\mathrm{Bu}$ yapılanmada; içerik, pedagoji ve pedagojik içerik olmak üzere üç temel bilgi alanı yer almaktadır. İçerik bilgisi, öğretilecek alan ile ilgili sahip olunan bilgileri ifade etmektedir (Harris ve diğ., 2007; Koehler \& Mishra, 2009). İçerik bilgisi, alana göre farklılık göstermekte ve uzmanlık alanından etkilenmektedir (Mishra ve Koehler, 2005). Konu alanı bilgileri alandaki temel kavram ve olguları anlamayı içermektedir. Öğretmenler, alanla ilgili kavram, kuram, fikir, organizasyonel çerçeveler, bilgi yapıları ve taksonomiler hakkında bilgi sahibi olmalıdır (Shulman, 1986). İçerik bilgisi ilköğretim, ortaöğretim ve yüksek öğretimde farklı kapsamda olmaktadır. Öğretimin seviyesi yükseldikçe sahip olunan bilginin düzeyi, uzmanlık seviyesi ve sorgulama düzeyi artmaktadır. Bu yönüyle öğretmenlerin kendi alanlarını temel düzeyde mutlaka bilmeleri gerekmektedir. Bunun yanında hangi öğretim seviyesinde öğretmenlik yapacaksa o seviyeye uygun bilgi seviyesine sahip olmalıdır. Ögretmenler kendi alanları ile ilgili bilgileri yeterli olmadığında, öğrenciler yanlış bilgiler edinebilmekte ve alanla ilgili kavram yanılgılarına sahip olabilmektedir (Koehler ve Mishra, 2009). Öğretmen yetiştirilmesinde öğretmenlerin sahip olması gereken içerik bilgileri, alan dersleri ile karşılanmaktadır.

Pedagoji bilgisi, öğrenme ve öğretim süreç, uygulama, strateji, yollar ya da yöntemlerin bilgisini ifade eder. Bunun yanında öğrencilerin öğrenmeleri, öğretim ve değerlendirme amaçları hakkında bilgileri de içerir (Mishra ve Koehler, 2006; Mishra ve Koehler, 2005). Pedagoji bilgisinde öğretmenin alanına bakılmaksızın ögretimle ilgili bilgi, alg1 ve genel becerileri ele alınmaktadır. Bu bilgi türünde alana özgü olmayan ve öğretim açısından sahip olunması gereken pedagojik bilgiler ön plana çıkmaktadır. Bu bilgi türü temel öğretim prensipleri, öğrencilerin gelişim ve öğrenme inançları, sınıf yönetimi, ölçme ve değerlendirme gibi bilgileri içermektedir. Pedagojik bilgi ile ilgili öğretmen adayları genel eğitim amaçları ve değerleri ile kuşatılmalıdır. $\mathrm{Bu}$ kuşatmada öğretmen adaylarına, öğrencilerin nasıl ögrendikleri, genel sınıf yönetimi becerileri ve değerlendirme ile ilgili 
bilgiler verilmektedir. Bir öğretmen derinlemesine pedagojik bilgi kazandığında, öğrencilerin nasıl anlam yapılandırdığı, nasıl beceri kazandığı, nasıl alışkanlık kazandığı ve öğrenmeye yönelik nasıl olumlu görüş geliştirdiğini anlamaktadır (Koehler \& Mishra, 2009). Öğretmenlerin sahip olması gereken pedagojik bilgiler, eğitim dersleri ile karşılanmaktadır.

Pedagojik içerik bilgisi, kavramsallaştırılmış öğretim bilgisinin özel bir alana uygulanabilirlik bilgisini içerir (Shulman, 1986). Pedagojik içerik bilgisi öğretmenlerin konu alanı bilgileri, genel pedagojik bilgileri ve bağlam bilgilerinden oluşan karmaşık ve üst düzey bilgi ve beceri gerektiren bir alandır. Öğretmen bu alanda öğretilecek konuları, öğrenci anlamaları, öğretim programı bilgisi, öğretim stratejileri bilgisi ve değerlendirme bilginin tümleşik bir yapıda konu alanına özgü hale getirilmesini içerir. Genel olarak alana özgü öğretimi ifade etmektedir. Shulman'a (1986) göre öğretmenin konu alanındaki öğretilecek konuyu incelemesi, bunları sunmak için farklı yollar araması, farklı kavramlar ve farklı ön bilgilere sahip öğrenciler için farklı öğretim materyali geliştirmesi pedagojik içerik bilgisinin içerisindedir. $\mathrm{Bu}$ bilgi türünde tümleşik ve karmaşık yapıda, alandaki yanlış anlaşılabilecek konu ve kavramlar, olası kavram yanılgıları ve bunların aşılması, konu alanında kullanılacak özel öğretim yöntemleri ve alanda bilgi öğretimi bulunmaktadır (Koehler \& Mishra, 2009). Öğretmen yetiştirilmesinde sahip olunması gereken pedagojik içerik bilgisi özel öğretim yöntemleri, öğretmenlik uygulaması gibi derslerle karşılanmaktadır.

Dünyada öğretmen yetiştirme yaklaşımında meydana gelen değişikliklerin yansımaları ülkemizdeki öğretmen yetiştirme yaklaşımını da değiştirmiştir. Ülkemizde 1982 yılına gelinceye kadar öğretmen yetiştirme farklı kurumlarda ve çeşitli programlar ile gerçekleştirilmiştir. Öğretmen yetiştirmede belli bir standardı yakalamak amacıyla bu görev 1982 yılında üniversitelerin öğretmen yetiştirme amaciyla açılmış olan fakültelerine devredilmiştir (YÖK, 2007). Öğretmen yetiştiren kurumlardaki öğretim programı 1997 yılında standartlara bağlanarak YÖK tarafından belirlenen dersler tüm eğitim fakültelerinde uygulanmaya başlanmıştır. Bu programda zaman içinde çeşitli değişlikler yapılmış ve son olarak 2006 yılında yan alanlar çıkarılıp, genel kültür ve alan derslerinin sayıları arttırılarak programa son hali verilmiştir. 2006 programının son halinde öğretmen yetiştirmede ele alınan ana boyutlar; alan bilgisi, meslek bilgisi (eğitim bilimleri, alan öğretim yöntemleri, öğretim yöntem ve teknikleri), genel kültür ve uygulama olarak belirlenmiştir (YÖK, 2007).

Ülkemizdeki bu yapılanmalar ile öğretmen yetiştirecek kurumların niteliklerinin artırılması ve standartlaştırılması hedeflenmiştir. Programlar YÖK tarafından belirlenmekte ve her fakültede benzer içerikle uygulanmaya çalışılmaktadır. Ancak her fakültenin bunu uygulayabilme olanakları aynı 
düzeyde değildir. $\mathrm{Bu}$ farklılıklar, yetiştirilen öğretmen adaylarının niteliklerini etkileyebilmektedir. Bulut ve Doğar (2006) ve Çelikkaya (2006) bu nitelikleri etkileyen faktörler arasında öğretmen yetiştirecek kurumun olanakları, sahip olduğu öğretim elemanlarının nitelikleri, öğretim programı, verilen eğitimin kalitesi, gelen öğrencinin motivasyon, ilgi, tutum, bilgi ve beceri düzeyleri gibi çeşitli faktörleri saymaktadır.

Öğretmen yetiştirecek kurumun sahip olduğu sınıf, sosyal tesis, teknolojik alt yapı, laboratuar gibi olanakların yeterliliği öğretmen yetiştirmede oldukça önemlidir. Bu olanaklara sahip olup olmamanın yanı sıra kurumdaki öğretim elemanları ile ilgili nitel ve nicel sorunlar da bulunmaktadır. Öğretmen yetiştirmede kalite sorunları çalıştayında (ÖYKSÇ) da vurgulanan bu sorunlar; akademik yetkinlik, akademik çalışma ortamının uygunluğu, kariyer basmaklarındaki dağılım oranları, değişim ve gelişime açık olma, tecrübe, akademik yayın, öğretim üyesi başına düşen öğrenci sayısı, alan dış1 ders yükü, iş yükü vb.dir (ÖYKSÇ, 2005: Mart).

Ülkenin sosyo-ekonomik şartlarındaki değişiklikler öğretmen yetiştirmede oldukça etkilidir. Dünyada ve Türkiye'de son yıllarda yaşanan ekonomik düzensizlikler işsizliği önemli ölçüde arttırmıştır. Geçmişte niteliksiz iş gücü için daha yüksek oranda olan işsizlik, günümüzde nitelikli iş gücünü tehdit eder konuma gelmiştir. Türkiye İstatistik Kurumunun açıkladığı genel işsizlik \%13.4 oranında iken üniversite mezunlarındaki işsizlik oranı \%14.2'dir (TUİK, 2009). Bu durum üniversiteden mezun olacak kişilerdeki gelecek kaygısında artışa neden olmaktadır (Kızılçaoğlu, 2003). Kamu personel sınavına giren öğretmen adaylarının istihdam edilebileceği en önemli kurum olan Milli Eğitim Bakanlığı'ndaki 6 yıllık (2004-2009) atanma oranlarına bakıldığında bilişim teknolojileri öğretmenlerinin \%61, psikolojik danışma ve rehberlik öğretmenlerinin \%58, sınıf öğretmenlerinin $\% 29$, fen bilgisi ve okul öncesi öğretmenlerinin $\% 15$, sosyal bilgiler öğretmenlerinin $\% 9$, elektronik öğretmenleri $\% 7$, yap1 ve otomotiv öğretmenlerinin $\% 1$ 'den düşük olduğu görülmektedir. $\mathrm{Bu}$ bölümlerin 6 yıla ait (2004-2009), yıl bazında başvuru ve atanma sayıları Ek 1 ve 2'de sunulmuştur. Atanma oranları öğrencilerin görüş, motivasyon, düşünce ve tutumlarını doğrudan etkileyen faktörlerden biridir (Kızılçaoğlu, 2003). Bu yönüyle bölümlere göre değişen atanma oranlarının öğrencilerin görüşlerinde farklılığa yol açması beklenmektedir.

Öğretmen yetiştiren fakültelere gelen öğrencilerin nitelikleri özellikle de motivasyonları çeşitli faktörlere bağlı olarak değişiklik göstermektedir. Öğrencilerin üniversiteye girişlerinde üniversitelerin herhangi bir seçim olanağı bulunmamakta, üniversite ve bölüm tercihi aldığı puana göre öğrenci tarafindan yapılmaktadır. Mesleğin sağladığı sosyal statü, iş bulma şansı, ekonomik getiri, psikolojik tatmin vb. etkenler öğrencilerin bölüm/program 
tercihlerini (Aksu, Daloğlu, Yıldırım, Kiraz ve Demir, 2008) ve dolayısıyla süreçte alacağı eğitimin niteliğini etkilemektedir. Üniversitede okuduğu bölümü bilinçli ve isteyerek tercih edenler ile istemediği halde puanı uygun olduğu için ya da bilinçsiz tercih nedeniyle bölümünden memnun olmayan öğrenciler derslere karşı farklı tutum ve düşüncelere sahip olmaktadır.

Ülkemizde öğretmen yetiştiren iki ana fakülte olan eğitim fakültesi ve mesleki ve teknik eğitim fakültelerinde farklı bölüm ve programlar bulunmaktadır. Bu programların öğrencileri oldukça farklılaşan üniversite giriş puanları ve tercih sıraları ile fakültelere gelmektedir. Mezun olduklarında ise farklı atanma oranları ve farklı çalışma şartları ile karşı karşıya kalmaktadırlar. Ayrıca teknik eğitim fakültesinin mezunlarının öğretmenlik yapmanın dışında sanayide çalışma olanaklarının bulunması onları eğitim fakültesi mezunlarından ayıran önemli bir faktördür. Öğretmenlik mesleğine bakışlarını etkilemesi olasıdır. Bu çalışmada eğitim ve teknik eğitim fakültelerinde öğrenim gören 4. Sınıf öğrencilerinin alan bilgisi dersleri, meslek bilgisi dersleri ve öğretmenliğe yönelik düşünceleri betimlenerek, tartışılması amaçlanmıştır.

\section{YÖNTEM}

$\mathrm{Bu}$ bölümde araştırmanın modeli, çalışma grubu, veri toplama aracı, verilerin toplanması ve verilerin analizi ile ilgili bilgiler yer almaktadır.

\section{Araştırmanın Modeli}

Araştırma, genel tarama modeli türlerinden ilişkisel tarama modelinde yürütülmüştür. Genel tarama modelleri çok sayıda elemandan oluşan bir evrende, evren hakkında genel bir yargiya varmak amacıyla, bir grup, örnek ya da çalışma grubu üzerinde yapılan tarama düzenlemeleridir. İlişkisel tarama modelleri, iki ve daha çok sayıdaki değişken arasındaki birlikte değişimi belirlemeyi amaçlayan araştırmalardır (Karasar, 1995). Bu araştırmada öğrencilerin eğitim ve alan derslerine yönelik düşünceleri ve öğretmenlik yapmak isteyip istemedikleri betimlenerek bunların öğrencilerin kişisel özelliklerine göre farklılık gösterip göstermediği incelenmiştir. İlişkisel çözümleme, karşılaştırma yoluyla gerçekleştirilmiştir.

\section{Çalışma Grubu}

Araştırmanın çalışma grubunu 2008-2009 öğretim y1lı bahar yarıyılında, Sakarya Üniversitesi Eğitim Fakültesi'nden 345 ve Teknik Eğitim Fakültesi'nden 100 olmak üzere toplam 445 dördüncü sınıf öğrencisi 
oluşturmuştur. Araştırmada alan, eğitim dersleri ve öğretmenliğe yönelik görüşler alınacağından eğitim ve teknik eğitim fakültelerinde okuyan ve bütün derslerini tamamlamak üzere olan 4. sınıf öğrencileri seçilmiştir. 445 öğrenciden 42'si demografik bilgileri eksik verdiği görülerek araştırmadan çıkarılmıştır. Sonuçta farklı bölümlerde okuyan toplam 403 öğrenci çalışma grubunu oluşturmuştur.

Öğrencilerin demografik özellikleri cinsiyet, fakülte, bölüm ve okuduğu bölümü isteyerek tercih edip etmediği olarak ele alınmıştır. Araştırmaya katılanların cinsiyetleri incelendiğinde öğrencilerinden 189'u (\%47) kadın, 214 ’ü (\%53) erkektir. Bu öğrencilerden 303'ü (\%75) eğitim fakültesi, 100’ü (\%25) ise teknik eğitim fakültesinde okuyan öğrencilerdir. Eğitim fakültesinde okuyanlardan 70'i $(\% 17,4)$ sinıf öğretmenliği, 64'ü $(\% 15,9)$ fen bilgisi öğretmenliği, 60'1 (\%14.9) bilgisayar ve öğretim teknolojileri öğretmenliği, 34'ü (\%8.4) sosyal bilgiler öğretmenliği, 46's1 (\%11.4) okul öncesi öğretmenliği ve 28'i (\%6.9) psikolojik danışma ve rehberlik bölümü öğrencilerinden oluşmaktadır. Teknik eğitim fakültesinde okuyanlardan 27'si (\%6.7) bilgisayar sistemleri öğretmenliği, 32'si (\%7.9) elektronik öğretmenliği, 22'si (\%5.5) otomotiv öğretmenliği ve 20'si (\%5) yap1 öğretmenliği bölümünün öğrencileridir. Öğrencilerden 301'i (\%74.7) okuduğu bölümü isteyerek tercih ettiğini ifade ederken, 102'si (\%25.3) ise okuduğu bölümü isteyerek tercih etmediğini vurgulamaktadır.

\section{Veri Toplama Aracı}

Araştırmada kullanılan anketin kişisel bilgiler bölümünde öğrencilerin cinsiyet, bölüm, fakülte ve bölümü isteyerek tercih edip etmeme değişkenleri ile ilgili bilgilere; anketin ikinci bölümünde ise açık uçlu üç soruya yer verilmiştir. Ankette yer alan açık uçlu sorular "Pedagojik formasyon derslerini gerekli ve önemli buluyor musunuz? Cevabınızın nedenini açıklayınız", "Kendi alanınızla ilgili derslere yönelik düşünceniz nedir? Cevabınızın nedenini açıklayınız" ve "Öğretmenlik yapmayı düşünüyor musunuz? Cevabınızın nedenini açıklayınız" sorularıdır. Anket araştırmacılar tarafından derslerinde karşılaştıkları sorunlar ve öğrenci ifadelerinden yola çıkarak şekillendirilmiş ve geliştirilmiştir. Araçta yer alan sorular araştırmacılar tarafindan yazılmış ve uzman görüşü almak üzere 2 eğitim teknoloğu, 1 ölçme değerlendirme, 1 psikolojik danışma ve rehberlik, 2 fen eğitimcisi, 1 sınıf öğretmenliği alanında olmak üzere toplam 7 uzmana verilmiştir. Uzman seçiminde nicel ve nitel araştırma yapmış olan kişiler tercih edilmiştir. Ancak teknik eğitim fakültesinden bir uzman alınmaması araştırmanın sınırlılı̆̆ıdır. Uzmanlardan alınan görüşler doğrultusunda 
sorular tekrar yapılandırılarak toplam 28 öğrenciye pilot uygulama amacıyla dağıtılmıştır. Pilot uygulamadaki öğrencilerden öncelikle soruları cevaplamaları istenmiş ve anlamadıkları sorular öğrencilerle tartışılarak soruların nasıl anlaşılır hale getirilebileceği hakkında bilgi elde edilmeye çalışılmıştır. Bunun yanında anketin farklı formlarından hangisinin daha rahat cevaplanabileceği ile ilgili görüss alınarak pilot uygulama tamamlanmıştır. Pilot uygulamada elde edilen verilerden hareketle soruların ifadelerinde gerekli düzeltmeler yapılarak ankete son hali verilmiştir.

\section{Verilerin Toplanması ve Verilerin Analizi}

Araştırmada kullanılacak olan anket basılı olarak çoğaltılmış ve öğrencilere elden dağıtılmıştır. Araştırmaya katılan kişilerin sorulara yönelik düşüncelerini ankete yazılı olarak ifade etmeleri istenmiştir. Elde edilen veriler öncelikle her soru için sayısal verilere çevirmek amacıyla kategorilere göre çözümlemeler yapılmıştır. Öğrencilerin her soruya yönelik verdikleri cevaplar kağıtlara yazılmış ve birbirine yakın olan cevaplar gruplandırılarak ankete bu grubun sahip olduğu numara yazılmıştır. Böylece veriler sayısallaştırılmıştır. Mayring'e (2000) göre açık uçlu sorulardan elde edilen nitel verilerin önemli bir özelliği anlamlı nicelleştirmelere olanak sağlamasıdır. Bu sayede nitel verilerden genelleme yapılabilen nicel veriler elde edilebilmektedir. Bu çalışmada da nitel veriler genelleme yapabilmek için nicel verilere çevrilmiştir. Sayısal değerlere çevrilen veriler yüzde ve frekans olarak verilmiştir. Elde edilen verilerden uygun olanlara ki kare istatistiği kullanılmıştır. Bu araştırmanın çalışma grubunun büyük olması (403 kişi) nedeniyle makalede, öğrencilerin her birinin ifadelerine yer vermek yerine birbirine yakın olanların birleștirilmesi yoluna gidilmiștir. Çalışmada bilimsel etiğe uygun olması açısından ve görüşlerin daha rahat ifade edilebilmesi için katılan öğrencilerin isimleri anketlere yazdırılmamıştır.

\section{BULGULAR}

$\mathrm{Bu}$ bölümde sırasıyla öğrencilerin "Pedagojik formasyon derslerini gerekli ve önemli buluyor musunuz? Cevabınızın nedenini açıklayınız", "Kendi alanınızla ilgili derslere yönelik düşünceniz nedir? Cevabınızın nedenini açıklayınız" ve "Öğretmenlik yapmayı düşünüyor musunuz? Cevabınızın nedenini açıklayınız" sorularına ilişkin görüşlerinin alındığı açık uçlu anketin verileri sırasıyla yer almaktadır. 
1. "Pedagojik formasyon derslerini gerekli ve önemli buluyor musunuz? Cevabınızın nedenini açıklayınız" sorusuna verilen cevaplar:

$\mathrm{Bu}$ soru üç ayrı bölümde incelenmiştir. İlk olarak öğrencilerin verdiği cevaplar pedagojik formasyon derslerini gerekli ve önemli bulup bulmama, ikinci olarak gerekli ve önemli bulup bulmamanın nedeni, üçüncü olarak ise gerekli/önemli bulma ile nedenleri arasındaki ilişki ve demografik faktörlere göre değişimi ele alınmıştır.

Araştırmaya katılan öğrencilerden $365^{\prime} \mathrm{i}(\% 90.6)$ pedagojik formasyon derslerini gerekli ve önemli bulduğunu, 28'i (\%6.9) gerekli ve önemli bulmadığını, 10'u (\%2.5) ise kararsız olduğunu ifade etmiştir. Araştırmaya katılan öğrencilerin pedagojik formasyon derslerini gerekli ve önemli bulup bulmamaları ile bunun nedenlerini ortaya koyan bilgiler Tablo 1'de yer almaktadır.

Tablo 1. Pedagojik formasyon derslerini gerekli bulup/bulmama ile nedenleri arasındaki ilişki

\begin{tabular}{|c|c|c|c|c|c|}
\hline & & Evet & Hayır & Kararsızım & Toplam \\
\hline $\begin{array}{l}\text { 0. Pedagojik formasyon derslerinin } \\
\text { gerekli ve önemli olup olmadlğg ile }\end{array}$ & $\mathrm{f}$ & 45 & 6 & 6 & 57 \\
\hline $\begin{array}{l}\text { ilgili herhangi bir gerekçe } \\
\text { yazılmamıs ya da ilgisiz bir açıklama } \\
\text { yapılmıs }\end{array}$ & $\%$ & 12.2 & 21.4 & 60 & 14.1 \\
\hline 1. Öğretmenlik mesleğinin kaliteli, & $\mathrm{f}$ & 243 & 0 & 0 & 243 \\
\hline verimli ve iyi yapılabilmesi için & $\%$ & 66.6 & 0 & 0 & 60.3 \\
\hline 2. KPSS sinavinda bu derslere & $\mathrm{f}$ & 16 & 0 & 2 & 18 \\
\hline yönelik sorular çıktı̆̆ı için & $\%$ & 4.4 & 0 & 20 & 4.5 \\
\hline 3. Dersler gerektiği gibi & $\mathrm{f}$ & 0 & 7 & 1 & 8 \\
\hline işlenmediğinden etkili olmadı̆̆g için & $\%$ & 0 & 25 & 10 & 2.0 \\
\hline 4. Öğretmenlik yapmayacă̆ı ya da & $\mathrm{f}$ & 0 & 15 & 0 & 15 \\
\hline atanamayacağı için & $\%$ & 0 & 53.6 & 0 & 3.7 \\
\hline $\begin{array}{l}\text { 5. Kendini ve insanları tanıma, is ve } \\
\text { yöneticilik hayatındaki ilişkilerini } \\
\text { yürütme, cocuk yetistirme ve cevreyle }\end{array}$ & $\mathrm{f}$ & 21 & 0 & 1 & 22 \\
\hline $\begin{array}{l}\text { olan iliş̧kileri düzenleme gibi } \\
\text { ögretmenlik dışındaki hayatta işe } \\
\text { yarayacağ için }\end{array}$ & $\%$ & 5.8 & 0 & 10 & 5.5 \\
\hline 1 ve 5 numaralı maddeleri birlikte & $\mathrm{f}$ & 40 & 0 & 0 & 40 \\
\hline ifade edenler & $\%$ & 11 & 0 & 0 & 9.9 \\
\hline
\end{tabular}

Pedagojik formasyon derslerini gerekli ve önemli bulan öğrencilerden 243’ü (\%66.6) "(1)Öğretmenlik mesleğinin kaliteli, verimli ve iyi yapılabilmesi için" gerekli ve önemli bulduğunu ifade etmiştir. 
Öğrencilerden 16's1 (\%4.4) pedagojik formasyon derslerini “(2) KPSS sınavında bu derslere yönelik sorular çıktığı için" gerekli ve önemli bulduğunu ifade etmiştir. Yine öğrencilerden 21'i (\%5.8) pedagojik formasyon derslerini “(5) Kendimi ve insanları tanıma, iş ve yöneticilik hayatımdaki ilişkilerimi yürütme, çocuk yetişstirme ve çevreyle olan ilişkileri düzenleme gibi ögretmenlik dışındaki hayatta işe yarayacă̆ için" gerekli ve önemli bulduğunu ifade etmiştir. 40 (\%11) öğrenci ise hem "(1)Öğretmenlik mesleğinin kaliteli, verimli ve iyi yapılabilmesi için" hem de "(5) Kendimi ve insanları tanıma, iş ve yöneticilik hayatımdaki ilişkilerimi yürütme, çocuk yetiştirme ve çevreyle olan ilişkileri düzenleme gibi ögrretmenlik dişındaki hayatta işe yarayacağl için" pedagojik formasyon derslerinin gerekli ve önemli olduğunu ifade etmiştir. Bunun yanında 45 (\%12.2) öğrenci ise pedagojik formasyon derslerinin gerekli ve önemli olmasıyla ilgili herhangi bir gerekçe yazmamıştır ya da ilgisiz bir açıklama yapmıştır.

Pedagojik formasyon derslerini gerekli ve önemli bulmayan öğrencilerden 15 ’i (\%53.6) “(4) Öğretmenlik yapmayacă̆ atanamayacağı için" gerekli ve önemli bulmadığını; 7'si (\%25) pedagojik formasyon derslerinin önemli olduğunu ancak "(3) Derslerin gerektiği gibi işlenmediği için etkili olmadığını" ifade etmiş; 6's1 (\%21.4) ise pedagojik formasyon derslerinin gerekli ve önemli olmamasiyla ilgili herhangi bir gerekçe yazmamış ya da ilgisiz bir açıklama yapmıştır.

Pedagojik formasyon derslerini gerekli ve önemli olması konusunda kararsız olan öğrencilerden 2'si (\%20) pedagojik formasyon derslerinin "(2) KPSS sınavinda sorular çıktı̆̆ için” gerekli ve önemli olabileceğini, 1 'i (\%10) "(5) Öğretmenlik dışındaki hayatta işine yarayacağı için" gerekli ve önemli olabileceğini, 1'i (\%10) ise "(3) Derslerin gerektiği gibi işlenmediği için etkili olmadığını" ifade etmiş; 6's1 (\%60) ise "(0) pedagojik formasyon derslerinin gerekli ve önemli olup olmadığ ile ilgili herhangi bir gerekçe yazmamışı ır ya da ilgisiz bir açıklama" yapmıştır.

Pedagojik formasyon derslerini gerekli ve önemli bulup bulmama sorusuna verilen cevaplarda dersleri gerekli bulan öğrencilerden bazıları bu derslerle ilgili çeşitli problemler olduğunu ifade etmişlerdir. Bu problemlerin kaynakları 4 başlıkta toplanabilir:

Derslerden kaynaklı problemler: Öğrencilerden 4'ü pedagojik formasyon dersleri ve içeriklerinin eksik olduğunu, 4 öğrenci derslerdeki konuların bir bölümünün gereksiz olduğunu, 9 öğrenci derslerin sadece bir bölümünün önemli olduğunu, 16 öğrenci derslerin kuramsal kaldığını ve uygulamasının eksik olduğunu, 2 öğrenci derslerin güncel ve özgün olmadığını, 5 öğrenci derslerin konularının gerçek yaşamda kullanılabilir ve gerçekçi olmadığını ve 1 öğrenci ise derslerin ona hiçbir şey katmadığını ifade etmiştir. Dersleri fazla ve gereksiz bulan öğrenciler, pedagojik 
formasyon derslerinin yerine alan dersi koyulması gerektiğini vurgulamışlardır. Yine öğrencilerden 5 'i staj derslerinin pedagojik formasyon derslerinin önemini anlamada etkili olduğunu ifade etmişlerdir.

Öğretim elemanlarından kaynaklı problemler: Öğrenciler öğretim elemanlarından kaynaklı problemleri üç farklı görüşte ifade etmişlerdir. Birinci görüsste öğretim elemanlarının bir bölümünün yetersiz olduğu, ikincide dersleri gerektiği gibi işlemediği, üçüncüsünde ise derslerle ilgili yaklaşımlarının uygun olmadığını ifade etmişlerdir. Öğretim elemanlarının yetersiz olduğu konusunda fikir beyan eden öğrencilerden 8'i öğretim elemanlarının akademik olarak yetersiz olduğunu, 9'u deneyim eksikliğinin olduğunu, 2'si ise öğretim elemanlarının da formasyon eğitimi alması gerektiğini vurgulamıştır. Öğretim elemanlarının işini gerektiği gibi yapmadığ1 konusunda fikir beyan eden öğrencilerden 12'si öğretim elemanlarının derse gereken önemi vermediğini, 10'u dersi öğrencilerin değil deneyimli öğretim elemanlarının anlatması gerektiğini, 4’ü ezberci eğitim yapılmaması gerektiğini, $8^{\prime} i$ ise derslerin sözel sunumlarla yapılmasının derslerin sıkıcı ve verimsiz hale gelmesine neden olduğunu ifade etmişlerdir. Bunun yanında 48 öğrenci derslerin niteliğinin yetersiz olduğunu bu nedenle derslerin niteliğinin arttırılması gerektiğini ifade etmiştir. 5 öğrenci ise öğretim elemanlarının dersin yürütülmesinde keyfi davrandıklarını ve sorgulanmadıklarını vurgulamıştır.

Öğrenciden kaynaklı problemler: 15 öğrenci, öğrencilerin derslere gereken önemi vermediğini, derslerin önemini sonradan (KPSS çalışırken gibi) anladığını ve yeni nesil öğretmen adaylarının bu derslerin öneminin farkına varamadığııı ifade etmiştir.

Sistemden kaynaklı problemler: 5 öğrenci eğitim ve teknik eğitim fakültesi programlarında derslerin uygun yerleştirilmediğini, 10 öğrenci ise bu dersleri almayanların öğretmen olarak atanmasının doğru bir yaklaşım olmadığını ifade etmiştir.

\section{Pedagojik formasyon derslerini gerekli bulma/bulmama ile cinsiyet arasındaki ki kare testi}

Araştırmaya katılan öğrencilerin pedagojik formasyon derslerini gerekli ve önemli bulup bulmamaları ile cinsiyetleri arasında istatistiksel olarak anlamlı bir ilişki bulunmuştur $\left(\chi_{(5)}^{2}=15.82, \mathrm{p}<.05\right)$. Kız öğrencilerin 181 'i (\%95.8) pedagojik formasyon derslerinin gerekli ve önemli olduğunu, 3’ü (\%1.6) gerekli ve önemli olmadığını, 5'i (\%2.6) ise kararsız olduğunu ifade etmiştir. Erkek öğrencilerden 184'ü (\%86) bu dersleri gerekli ve önemli bulurken, 25'i (\%11.7) gerekli ve önemli bulmadığını ve 5'i (\%2.3) ise kararsız olduğunu ifade etmiştir. Bu bulgu, kızların pedagojik formasyon derslerini daha çok gerekli ve önemli bulduğunu göstermektedir. 


\section{Pedagojik formasyon derslerini gerekli bulma/bulmama ile fakülte arasındaki ki kare testi}

Araştırmaya katılan öğrencilerin pedagojik formasyon derslerini gerekli ve önemli bulup bulmamaları ile fakülteleri arasında istatistiksel olarak anlamlı bir ilişki bulunmuştur $\left(\chi_{(2)}^{2}=29.49, \quad \mathrm{p}<.05\right)$. Eğitim fakültesi öğrencilerinden 288 'i (\%95) pedagojik formasyon derslerinin gerekli ve önemli olduğunu, 10’u (\%3.3) gerekli ve önemli olmadığını, 5’i (\%1.6) ise kararsız olduğunu ifade etmiştir. Teknik eğitim fakültesi öğrencilerinden 77'si (\%77) bu dersleri gerekli ve önemli bulurken, 18'i (\%18) gerekli ve önemli bulmadığını ve 5'i (\%5) ise kararsız olduğunu ifade etmiştir. Bu bulgu, eğitim fakültesi öğrencilerinin pedagojik formasyon derslerini teknik eğitim fakültesi öğrencilerine göre daha çok gerekli ve önemli bulduğunu göstermektedir.

Pedagojik formasyon derslerini gerekli bulma/bulmama ile bölümü isteyerek mi tercih ettiği arasındaki ki kare testi

Araştırmaya katılan öğrencilerin pedagojik formasyon derslerini gerekli ve önemli bulup bulmamaları ile okuduğu bölümü isteyerek tercih edip etmeme arasında istatistiksel olarak anlamlı bir ilişki bulunmuştur $\left(\chi_{(2)}^{2}=12.97, p<.05\right)$. Okuduğu bölümü isteyerek tercih eden öğrencilerden 281'i (\%93.4) pedagojik formasyon derslerinin gerekli ve önemli olduğunu, 13'ü (\%4.3) gerekli ve önemli olmadığını, 7'si (\%2.3) ise kararsız olduğunu ifade etmiştir. Okuduğu bölümü istemeyerek tercih eden öğrencilerin 84'ü (\%82.4) bu dersleri gerekli ve önemli bulurken, 15'i (\%14.7) gerekli ve önemli bulmadığını ve 3'ü (\%2.9) ise kararsız olduğunu ifade etmiştir. Bu bulgu, okuduğu bölümü isteyerek tercih eden öğrencilerin pedagojik formasyon derslerini istemeden tercih eden öğrencilere göre daha çok gerekli ve önemli bulduğunu göstermektedir.

Pedagojik formasyon derslerini gerekli bulma/bulmama ile bölümlerin/programların atanma oranları arasındaki ki kare testi

Araştırmaya katılan öğrencilerin pedagojik formasyon derslerini gerekli ve önemli bulup bulmamaları ile son altı y1la göre bölümlerin/programların atanma oranları arasında istatistiksel olarak anlamlı bir ilişki bulunmuştur $\left(\chi_{(8)}^{2}=64.33, p<.05\right)$. Bölüm/programlardan atanma oranlar1 \%50'den yüksek olan bilgisayar ve öğretim teknolojileri, bilgisayar sistemleri ve psikolojik danışma ve rehberlik öğretmenliği bölümlerinin öğrencilerinden 109'u (\%94.8) pedagojik formasyon derslerinin gerekli ve önemli olduğunu, 1'i (\%0.9) gerekli ve önemli olmadığını, 5'i (\%4.3) ise kararsız olduğunu ifade etmiştir. Atanma oranı \%20'den yüksek olan sınıf öğretmenliği öğrencilerinden $65^{\prime} \mathrm{i}(\% 91.4)$ bu dersleri gerekli ve önemli bulurken, 5'i (\%7.2) gerekli ve önemli bulmadığını, 1'i (\%1.4) ise kararsız olduğunu ifade etmiştir. Atanma oranları \%10'dan yüksek olan fen bilgisi ve okul öncesi 
öğretmenliği bölümlerinin öğrencilerinden 103’ü (\%93.6) bu dersleri gerekli ve önemli bulurken, 5'i (\%4.5) gerekli ve önemli bulmadığını, 2'si (\%1.9) ise kararsız olduğunu ifade etmiştir. Atanma oranları $\% 5$ 'den yüksek olan sosyal bilgiler ve elektronik öğretmenliği bölümlerinin öğrencilerinden 56's1 (\%84.8) bu dersleri gerekli ve önemli bulurken, 5’i (\%7.6) gerekli ve önemli bulmadığını, 5'i (\%7.6) ise kararsız olduğunu ifade etmiş̦tir. Atanma oranları $\% 5$ 'den düşük olan yap1 ve otomotiv öğretmenliği bölümlerinin öğrencilerinden 25 'i (\%59.5) bu dersleri gerekli ve önemli bulurken, 12'si (\%28.6) gerekli ve önemli bulmadığını, 5'i (\%11.9) ise kararsız olduğunu ifade etmiştir. Bu bulgu, atanma oranları yüksek olan bölümlerde okuyan öğrencilerin pedagojik formasyon derslerini atanma oranları düşük olan bölümlerde okuyan öğrencilere göre daha çok gerekli ve önemli bulduğunu göstermektedir.

2. "Kendi alanınızla ilgili aldığınız derslere yönelik düşünceniz nedir? Cevabınızın nedenini açıklayınız." sorusuna verilen cevaplar:

Araştırmaya katılan öğrencilerin alanlarındaki derslere yönelik görüşleri üç grupta toplanmıştır. Birinci grupta yer alan 186 öğrenci alan derslerinin tamamının gerekli ve önemli olduğunu; ikinci grupta yer alan 164 öğrenci alan derslerinin büyük bir bölümünün gerekli, bazı derslerin gereksiz olduğunu; üçüncü grupta yer alan 36 öğrenci ise derslerin çok büyük kısmını gereksiz ya da derslerin çok fazla olmasından dolayı yeterince yararlanamadıklarını ifade etmiştir. Birinci grupta yer alan öğrencilerin 104'ü (\%55.9) "alandaki derslerin oldukça önemli olduğunu, bu dersleri sevdiğini ve insanın hayata ve mesleğe baklşını etkilediğini" ifade etmiş, alandaki derslerin çok önemli ve gerekli olduğunu vurgulamıştır. Bu öğrencilere ek olarak 44 öğrenci (\%23.7) “alandaki derslerin oldukça önemli olduğunu, bu dersleri sevdiğini ve insanın hayata ve mesleğe bakışını etkilediğini ancak derslerin daha geniş zamanda, verimliliği artırllarak, güncelleştirilerek, uygulamaları arttırılarak ve programdaki dağılımı değiştirilerek verilmesi gerektiğini", 25 öğrenci (\%13.4) "alandaki derslerin oldukça önemli olduğunu, bu dersleri sevdiğini ve insanın hayata ve mesleğe bakışını etkilediğini ancak derslerin bir kısmının verimli işlenmediği için yeterli olmadığını", 13 (\%7.0) öğrenci ise "alandaki derslerin oldukça önemli olduğunu, bu dersleri sevdiğini ve insanin hayata ve mesleğe bakışını etkilediğini ancak derslerin toplaminın fazla ve ă̆ır geldiğini ve bazı derslerde fazla ayrıntıya girildiğini" ifade etmiştir. Bu grupta yer alan öğrencilerin tamamı alan derslerinin tamamının önemli ve gerekli olduğunu ifade etmişlerdir. Bu öğrencilerden 82'si (\%44.1) bu derslerden bazılarının gerektiği gibi işlenmediği için verimsiz olduğunu ifade etmiştir. 
İkinci grupta yer alan öğrencilerden 97'si (\%59.1) “alan derslerinin birçoğunun gerekli olduğunu ancak alan derslerinden bazlarının gereksiz olduğunu” ifade etmiştir. Bu öğrencilere ek olarak 67 öğrenci (\%40.9) "alan derslerinin birçoğunun gerekli olduğunu ancak verimli işlenmeyen bir kısım alan derslerinin gereksiz olduğunu, bu dersleri gerekli hale getirmek için daha geniş zamanda, verimliliği artırllarak, güncelleş̧tirilerek, uygulamaları arttırılarak ve derslerin programdaki dağılımı değiştirilerek verilmesi gerektiğini" ifade etmiştir. Bu grupta yer alan öğrenciler ise alan derslerinin büyük bir bölümünün gerekli olduğunu ancak gerektiği gibi işlenmeyen ve bu yüzden verimli olmayan bazı derslerin gereksiz olduğunu ifade etmişler ve bunları verimli hale getirmek için bazı önerilerde bulunmuşlardır.

Üçüncü grupta yer alan öğrencilerden 23'ü (\%63.9) “derslerin toplamının fazla ve ă̆ır geldiğini ve bazı derslerde fazla ayrıntıya girildiğini" vurgulamıştır. Bunun yanında 13 öğrenci (\%36.1) ise "derslerin önemli bir kısmının gereksiz" olduğunu ifade etmiştir. Bu gruptaki öğrenciler ise derslerin çok büyük kısmını gereksiz görmekte ya da dersler çok fazla olduğu için yeterince yararlanamadıklarını ifade etmişlerdir. Tüm bu öğrencilerin yanında 17 (\%4.2) öğrenci ise hiçbir gerekçe yazmamış ya da ilgisiz bir açıklama yaptıkları için gerekçe yazılmamış olarak sınıflanmışlardır.

Alanlarındaki derslere yönelik görüşleri sorusuna verdiği cevaplarda bir kısım derslerde problem olduğunu ifade eden öğrencilerin belirttikleri problem kaynakları iki başlıkta toplanabilir niteliktedir. Bunlar:

Akademik personelden kaynaklanan problemler: Akademik personelden kaynaklanan problemler olduğu 30 öğrenci tarafından ifade edilmiştir. Bu öğrencilerden bir kısmı bazı öğretim elemanlarının akademik olarak yetersiz olduğunu, bir kısmı ise dersin işlenişinin doğru stratejilerle yürütülmediğini ifade etmiş ve bu problemlerin öğrencilerin dersten yararlanma oranını düşürdügünü vurgulamışlardır.

Program ve derslerden kaynaklanan problemler: $\mathrm{Bu}$ problemle ilgili 69 öğrenci öğretim programından ve ders içeriklerinden memnun olmadığını ifade etmiştir. Bu öğrencilerden 24'ü kendilerine uygulanan öğretim programının yeterli olmadığını, 2006'dan itibaren uygulanmaya başlayan öğretim programının daha iyi olduğunu vurgulamıştır. 10 öğrenci bazı derslerin gelecekte kullanmayacağı için gereksiz olarak gördüğünü ifade etmiştir. 6 öğrenci zorunlu seçmeli olarak tanımladıkları derslerin işlevsel olmadığını, 18 öğrenci ilköğretim programındaki konuları içeren veya öğretmenlik uygulamasına yönelik yeni dersler eklenmesi gerektiğini, 5 öğrenci alan derslerinin sürelerinin yetersiz olduğunu ve 4 öğrenci ise ödev ve kısa sınav gibi uğraşların çok fazla olduğunu ifade etmiştir. 2 öğrenci 
değerlendirmenin uygulamalı yapılmadığını, 3 öğrenci çok fazla ders olduğu için sosyalleşme problemi yaşadığını, 2 öğrenci ise yoğunlaşmakta zorluk çektiğini vurgulamıştır.

Tüm bunların yanında 9 öğrenci ise alan derslerinin zor ve zaman alıcı olmasına rağmen meslekle ilgili bilgi, beceri ve ilgilerini arttırdığ 1 için olumlu görüş ifade etmişlerdir.

3. "Öğretmenlik yapmayı düşünüyor musunuz? Cevabınızın nedenini açıklayınız." sorusuna verilen cevaplar:

Araştırmada öğrencilere üçüncü olarak "Öğretmenlik yapmayı düşünüyor musunuz? Cevabınızın nedenini açıklayınız" sorusu sorulmuş ve alınan cevaplar üç ayrı bölümde incelenmiştir. Öğrencilerin verdiği cevaplar ilk olarak öğretmenlik yapmayı düşünüp düşünmeme, ikinci olarak öğretmenliği yapıp yapmayacağının nedenleri, üçüncü olarak da öğretmenliği yapıp yapmayacağı ile nedenleri arasındaki ilişki ve demografik faktörlere göre değişimi olarak çözümlenmiştir.

Araştırmaya katılan öğrencilerden 278'i (\%69) öğretmenlik yapmayı düşündügünü, 70’i (\%17.4) atanırsa öğretmenlik yapmayı düşündüğünü, 9'u (\%2.2) öğretmen olmayı istediğini ancak bunun çok zor olduğunu, 46's1 (\%11.4) ise öğretmenlik yapmayı düşünmediğini ifade etmiştir. Araştırmaya katılan öğrencilerin öğretmenlik yapmayı düşünüp/düşünmemeleri ile bunun nedenlerini ortaya koyan bilgiler Tablo 2'de yer almaktadır.

Öğretmenlik yapmayı düşünen öğrencilerden 167'si (\%60) bunun nedeni olarak "(1) çocukları sevmesi, insan yetiştirmeyi önemsemesi ve idealindeki meslek olması gibi nedenlerle öğretmenlik mesleğini sevdiğinden dolayl" öğretmenlik yapacağını ifade etmiştir. Öğrencilerden 58'i (\%20.9) “(2) ailesinin beklentilerine cevap verme, başka bir işi yapabilme olanağının olmayışı, istemeyerek de gelse yıllarca verdiği emeğin karşılığını alma isteği gibi nedenlerle zorunlu olarak" öğretmenlik yapacağını ifade etmiştir. Yine öğrencilerden 20'si (\%7.2) “(3) iş güvencesinin olmast, ekonomik durumunun iyi olması ve çalışma şartlarının uygun olması, mesleki saygınlık gibi nedenlerle mesleğin uygun olmasından dolayl" öğretmenlik yapacağını ifade etmiştir. Öğrencilerden 6’s1 (\%2.2) “(4) yüksek lisans yapmak veya devlette çalışarak kendini geliştirmeyi düşündükleri için" öğretmenlik yapacağını ifade etmiştir. 14 (\%5) öğrenci ise hem "çocukları sevmesi, insan yetiştirmeyi önemsemesi ve idealindeki meslek olması gibi nedenlerle ögretmenlik mesleğini sevdiğinden dolayı" hem de "iş güvencesinin olması, ekonomik durumunun iyi olması ve çalışma şartlarının uygun olması, mesleki saygınlık gibi nedenlerle mesleğin uygun olmasindan dolayl" öğretmenlik yapacağını ifade etmiştir. Bunun yanında 10 (\%3.6) öğrenci “(6) önceliğinin ögretmenliğe atanmak olduğunu ancak atanamadiğı takdirde 
başka işler yapmayl düşündüğünü̈’, 3 (\%1.1) öğrenci ise öğretmenlik yapmak istemesi ile ilgili herhangi bir gerekçe yazmamış ya da ilgisiz bir açıklama yapmıştır.

Tablo 2. Öğretmenlik yapmayı düşünüp/düşünmeme ve bunun nedenlerinin çapraz tablosu

\begin{tabular}{|c|c|c|c|c|c|c|}
\hline & & Evet & Hayır & Atanırsam & İsterim ama çok zor & Toplam \\
\hline 0. Herhangi bir gerekçe yazmamış & $\mathrm{f}$ & 3 & 1 & 8 & 1 & 13 \\
\hline ya da ilgisiz bir açılama yapmış & $\%$ & 1.1 & 2.2 & 11.4 & 11.1 & 3.2 \\
\hline $\begin{array}{l}\text { 1. Cocuklarl sevmesi, insan } \\
\text { yetistirmeyi önemsemesi ve }\end{array}$ & $\mathrm{f}$ & 167 & 0 & 16 & 0 & 183 \\
\hline $\begin{array}{l}\text { idealindeki meslek olması gibi } \\
\text { nedenlerle ögretmenlik mesleğini } \\
\text { sevdiğinden dolayı }\end{array}$ & $\%$ & 60.1 & 0 & 22.9 & 0 & 45.4 \\
\hline $\begin{array}{l}\text { 2. Ailesinin beklentilerine cevap } \\
\text { verme, başka bir işi yapabilme }\end{array}$ & $\mathrm{f}$ & 58 & 0 & 7 & 0 & 65 \\
\hline $\begin{array}{l}\text { olanağının olmayışsl, istemeyerek de } \\
\text { gelse yıllarca verdiği emeğin } \\
\text { karşllığın alma isteği gibi } \\
\text { nedenlerle zorunlu olarak }\end{array}$ & $\%$ & 20.9 & 0 & 10 & 0 & 16.1 \\
\hline $\begin{array}{l}\text { 3. İs güvencesinin olmast ekonomik } \\
\text { durumunun iyi olmast ve çalışma }\end{array}$ & $\mathrm{f}$ & 20 & 0 & 7 & 2 & 29 \\
\hline $\begin{array}{l}\text { şartlarınin uygun olmasl, mesleki } \\
\text { sayginllk gibi nedenlerle mesleğin } \\
\text { uygun olmasindan dolayl }\end{array}$ & $\%$ & 7.2 & 0 & 10 & 22.2 & 7.2 \\
\hline 4. Yüksek lisans yapmak veya & $\mathrm{f}$ & 6 & 0 & 0 & 1 & 7 \\
\hline $\begin{array}{l}\text { devlette çalışarak kendini } \\
\text { gelişistirmeyi düşündükleri için }\end{array}$ & $\%$ & 2.2 & 0 & 0 & 11.1 & 1.7 \\
\hline 5. Akademisyen olmak veya & $\mathrm{f}$ & 0 & 20 & 11 & 3 & 34 \\
\hline $\begin{array}{l}\text { ekonomik nedenlerden dolayı başka } \\
\text { işler yapmak istediğinden dolayl }\end{array}$ & $\%$ & 0 & 43.5 & 15.7 & 33.3 & 8.4 \\
\hline $\begin{array}{l}\text { 6. Önceliğinin ögretmenliğe } \\
\text { atanmak olduğunu ancak }\end{array}$ & $\mathrm{f}$ & 10 & 1 & 18 & 2 & 30 \\
\hline $\begin{array}{l}\text { atanamadığı takdirde başka işler } \\
\text { yapmayl düşündügü için }\end{array}$ & $\%$ & 3.6 & 2.2 & 25.7 & 22.2 & 7.4 \\
\hline $\begin{array}{l}\text { 7. KPSS ve staj sürecinden olumsuz } \\
\text { etkilenip meslekten soğuma, sürekli } \\
\text { aynı şeyleri yapmayı sıkıc bulma }\end{array}$ & $\mathrm{f}$ & 0 & 21 & 3 & 0 & 24 \\
\hline $\begin{array}{l}\text { ve mesleği beğenmeme gibi } \\
\text { nedenlerle mesleği yapmayacă̆ } \\
\text { için }\end{array}$ & $\%$ & 0 & 45.7 & 4.3 & 0 & 6.0 \\
\hline 8. Kendini ögretmen olarak & $\mathrm{f}$ & 0 & 4 & 0 & 0 & 4 \\
\hline $\begin{array}{l}\text { görmediginden ögretmenlik } \\
\text { yapmayacağı için }\end{array}$ & $\%$ & 0 & 8.7 & 0 & 0 & 1 \\
\hline 1 ve 3 numaralı maddeleri birlikte & $\mathrm{f}$ & 14 & 0 & 0 & 0 & 14 \\
\hline ifade edenler & $\%$ & 5 & 0 & 0 & 0 & 5 \\
\hline
\end{tabular}

Atanırsa öğretmenlik yapmayı düşünen öğrencilerden 16's1 (\%22.9) bunun nedeni olarak "(1) çocuklarl sevmesi, insan yetiştirmeyi önemsemesi ve idealindeki meslek olması gibi nedenlerle ögretmenlik mesleğini sevdiğinden dolayl" atanabilirse öğretmenlik yapacağını ifade etmiştir. 
Öğrencilerden 7'si (\%10) “(2) ailesinin beklentilerine cevap verme, başka bir işi yapabilme olanağının olmayışı, istemeyerek de gelse yıllarca verdiği emeğin karşıllı̆ııı alma isteği gibi nedenlerle zorunlu olarak" atanabilirse öğretmenlik yapacağını ifade etmiştir. Yine öğrencilerden 7'si (\%10) “(3) iş güvencesinin olması, ekonomik durumunun iyi olması ve çalışma şartlarının uygun olması, mesleki sayginlık gibi nedenlerle mesleğin uygun olmasindan dolayl" atanabilirse öğretmenlik yapacağını ifade etmiştir. Bunun yanında 18 (\%25.7) öğrenci "(6) atanamadiğı takdirde başka işler yapmayı düşündü̈̆̈̈nü”, 11 (\%15.7) öğrenci “(5) akademisyen olmak veya ekonomik nedenlerden dolayı başka işler yapmak istediğini”, 3 (\%4.3) öğrenci ise "(7) KPSS ve staj sürecinden olumsuz etkilenip meslekten soğuma, sürekli ayn şeyleri yapmayl slkıcı bulma ve mesleği beğenmeme gibi nedenlerle mesleği yapmayacă̆ını" ifade etmişlerdir. 8 (\%11.4) öğrenci ise atanabilirse öğretmenlik yapmak istemesi ile ilgili herhangi bir gerekçe yazmamış ya da ilgisiz bir açıklama yapmışlardır.

Öğretmenlik yapmayı düşünen ancak bunun çok zor olduğunu ifade eden öğrencilerden 2'si (\%22.2) “(3) iş güvencesinin olmasl, ekonomik durumunun iyi olması ve çalışma şartlarının uygun olması, mesleki saygınlık gibi nedenlerle mesleğin uygun olmasından dolayl”, 1'i (\%11.1) “(4) yüksek lisans yapmak veya MEB'e bağlı kurumlarda çalışarak kendini geliş̧tirmeyi düşündükleri için" öğretmenlik yapmak istediğini ancak bunun çok zor olduğunu ifade etmiştir. Bunun yanında 3 (\%33.3) öğrenci "(5) akademisyen olmak veya ekonomik nedenlerden dolayı başka işler yapmak istediğini”, 2 (\%22.2) öğrenci ise "(6) atanamadĭ̆ı takdirde başka işler yapmayı düşündüğünü̈” ifade etmiştir. Tüm bunların yanında 1 (\%11.1) öğrenci ise öğretmenlik yapmak istediğini ancak bunun çok zor olması ile ilgili herhangi bir gerekçe yazmamış ya da ilgisiz bir açıklama yapmıştır.

Öğretmenlik yapmayı düşünmeyen öğrencilerden 21’i (\%45.6) “(7) KPSS ve staj sürecinden olumsuz etkilenip meslekten soğuma, sürekli ayn şeyleri yapmayı sıkıcı bulma ve mesleği beğenmeme gibi nedenlerle mesleği yapmayacă̆ını", 20'si (\%43.5) “(5) akademisyen olmak veya ekonomik nedenlerden dolayı başka işler yapmak istediğini" ve 4'ü (\%8.7) "(8) kendini ögretmen olarak görmediği için öğretmenlik yapmayacağını” ifade etmiştir. Öğrencilerden 1'i ise “(6) atanamadiğl takdirde başka işler yapmayı düşündügünü" ifade etmiştir. Tüm bunların yanında 1 (\%2.2) öğrenci ise öğretmenlik yapmak istememesi ile ilgili herhangi bir gerekçe yazmamış ya da ilgisiz bir açıklama yapmıştır. 


\section{Öğrencilerin öğretmen olmayı düşünmeleri/düşünmemeleri ile cinsiyetleri arasındaki ki kare testi}

Araştırmaya katılan öğrencilerin öğretmen olmayı düşünüp düşünmemeleri ile cinsiyetleri arasında istatistiksel olarak anlamlı bir ilişki bulunmuştur $\left(\chi_{(3)}^{2}=40.92, p<.05\right)$. Kız öğrencilerin 149'u (\%78.9) öğretmen olmak istediğini, 30'u (\%15.9) atandığı takdirde öğretmen olacağını, 5'i (\%2.6) öğretmen olmak istediğini ancak bunun çok zor olduğunu, 5'i (\%2.6) ise öğretmen olmak istemediğini ifade etmiştir. Erkek öğrencilerin 129'u (\%60.3) öğretmen olmak istediğini, 40’’ (\%18.7) atandığ takdirde öğretmen olacağını, 4’ü (\%1.9) öğretmen olmayı istediğini ancak bunun çok zor olduğunu, 41'i (\%19.1) ise öğretmen olmak istemediğini ifade etmiştir. Bu bulgu, kız öğrencilerin, erkeklere göre daha çok öğretmen olmak istediğini göstermektedir.

Öğrencilerin öğretmen olmayı düşünmeleri/düşünmemeleri ile fakülteleri arasındaki ki kare testi

Araştırmaya katılan öğrencilerin öğretmen olmayı düşünüp düşünmemeleri ile fakülteleri arasında istatistiksel olarak anlamlı bir ilişki bulunmuştur $\left(\chi_{(3)}^{2}=67.37, p<.05\right)$. Eğitim fakültesi öğrencilerinden 234'ü (\%77.2) öğretmen olmak istediğini, 49’u (\%16.2) atandığ takdirde öğretmen olacağını, 7'si (\%2.3) öğretmen olmayı istediğini ancak bunun çok zor olduğunu, 13'ü (\%4.3) ise öğretmen olmak istemediğini ifade etmiştir. Teknik eğitim fakültesi öğrencilerinden 44'ü (\%44) öğretmen olmak istediğini, 21'i (\%21) atandığı takdirde öğretmen olacağını, 2'si (\%2) öğretmen olmak istediğini ancak bunun çok zor olduğunu, 33'ü (\%33) ise öğretmen olmak istemediğini ifade etmiştir. Bu bulgu, eğitim fakültesi öğrencilerinin öğretmen olmayı teknik eğitim fakültesi öğrencilerine göre daha çok istediklerini göstermektedir.

Öğrencilerin öğretmen olmayı düşünmeleri/düşünmemeleri ile okudukları bölümü isteyerek/istemeyerek tercih etmeleri arasındaki ki kare testi

Araştırmaya katılan öğrencilerin öğretmen olmayı düşünüp düşünmemeleri ile okuduğu bölümü isteyerek tercih edip etmemeleri arasında istatistiksel olarak anlamlı bir ilişki bulunmuştur $\left(\chi_{(3)}^{2}=13.04\right.$, $\mathrm{p}<.05)$. Okuduğu bölümü isteyerek tercih eden öğrencilerden 222'si (\%73.8) öğretmen olmak istediğini, 44'ü (\%14.5) atandığ 1 takdirde öğretmen olacağını, 5'i (\%1.7) öğretmen olmak istediğini ancak bunun çok zor olduğunu, 30'u (\%10) ise öğretmen olmak istemediğini ifade etmiştir. Okuduğu bölümü istemeyerek tercih eden öğrencilerinden 56's1 (\%54.9) öğretmen olmak istediğini, 26's1 (\%25.5) atandığı takdirde öğretmen olacağını, 4'ü (\%3.9) öğretmen olmak istediğini ancak bunun çok zor olduğunu, 16's1 (\%15.7) ise öğretmen olmak istemediğini ifade etmiştir. Bu 
bulgu, okuduğu bölümü isteyerek tercih eden öğrencilerin öğretmen olmayı, okuduğu bölümü istemeden tercih eden öğrencilere göre daha çok istediğini göstermektedir.

Öğrencilerin öğretmen olmayı düşünme/düşünmeme ile bölümleri/programları atanma oranları arasındaki ki kare testi

Araştırmaya katılan öğrencilerden öğretmen olmay1

düşünme/düşünmeme ile son altı yıla göre bölümlerin/programların atanma oranları arasında istatistiksel olarak anlamlı bir ilişki bulunmuştur $\left(\chi_{(8)}^{2}=64.33, p<.05\right)$. Bölüm/programlardan atanma oranlar1 \%50'den yüksek olan bilgisayar ve öğretim teknolojileri, bilgisayar sistemleri, psikolojik danışma ve rehberlik öğretmenliği bölümleri öğrencilerinden 97'si (\%84.3) öğretmen olmayı düşündügünü, 10'u (\%8.7) atanırsa öğretmen olmayı düşündüğünü, 1’i (\%0.9) öğretmen olmayı istediğini ama bunun çok zor olduğunu ve 7'si (\%6.1) ise öğretmen olmayı düşünmediğini ifade etmiştir. Atanma oran1 \%20'den yüksek olan sınıf öğretmenliği öğrencilerinden 49'u (\%70) öğretmen olmayı düşündügünü, 15'i (\%21.4) atanırsa öğretmen olmayı düşündüğünü, 1'i (\%1.4) öğretmen olmayı istediğini ama bunun çok zor olduğunu ve 5 'i $(\% 7.1)$ ise öğretmen olmayı düşünmediğini ifade etmiştir. Atanma oranları \%10'dan yüksek bölümler olan fen bilgisi ve okul öncesi öğretmenliği öğrencilerinden 90’1 (\%81.9) öğretmen olmayı düşündügünü, 15 'i (\%13.6) atanırsa öğretmen olmayı düşündüğünü ve 5'i (\%4.5) ise öğretmen olmayı istediğini ama bunun çok zor olduğunu ifade etmiştir. Atanma oranları $\% 5$ 'den yüksek bölümler olan sosyal bilgiler ve elektronik öğretmenliği öğrencilerinden 36's1 (\%54.5) öğretmen olmayı düşündügünü, 15 'i (\%22.7) atanırsa öğretmen olmayı düşündügünü, 5'i (\%7.6) öğretmen olmayı istediğini ama bunun çok zor olduğunu ve 10'u (\%15.2) ise öğretmen olmayı düşünmediğini ifade etmiştir. Atanma oranları $\% 5$ 'den düşük bölümler olan yap1 ve otomotiv öğretmenliği öğrencilerinden 6's1 (\%14.3) öğretmen olmayı düşündüğünü, 10’u (\%23.8) atanırsa öğretmen olmayı düşündügünü ve 26'sı (\%61.9) ise öğretmen olmayı düşünmediğini ifade etmiştir. $\mathrm{Bu}$ bulgu, atanma oranları yüksek olan bölümlerin öğrencilerinin öğretmen olmayı daha çok istediğini göstermektedir.

\section{SONUÇ, TARTIŞMA VE ÖNERILER}

Araştırmada öğrencilere ilk olarak "Pedagojik formasyon derslerini gerekli ve önemli buluyor musunuz? Cevabınızın nedenini açıklayınız" sorusu sorulmuş ve alınan cevaplar üç ayrı bölümde incelenmiştir. Öğrencilerin verdiği cevaplar ilk olarak pedagojik formasyon derslerinin gerekli ve önemli bulup bulmama, ikinci olarak gerekli ve önemli bulup bulmamanın nedenleri, üçüncü olarak gerekli/önemli bulma ile nedenleri 
arasındaki ilişki ve demografik faktörlere göre değişimi olarak çözümlenmiştir.

Araştırmaya katılan öğrencilerden \%90.6's1 pedagojik formasyon derslerini gerekli ve önemli bulduğunu, \%6.9'u gerekli ve önemli bulmadığını, \%2.5'i kararsız olduğunu ifade etmişlerdir. Araştırmada elde edilen bu sonuç Deniz (1998), Ekici (2008), Kılıç (2007) ve Semerci'nin (2004) bulguları ile tutarlı bulgular içermektedir. Araştırma öğretmen yetiştiren fakültelerde gerçekleştirildiği için öğretmenlik formasyon derslerinin gerekli ve önemli olarak ifade edilmesi beklenen bir bulgudur.

Pedagojik formasyon derslerinin gereği ve öneminin farkında olan öğrencilerden \%66.6's1 bu derslerin iyi bir öğretmen olabilmek için, \%32.4'ü KPSS sınavı ve günlük hayatta çeşitli durumlarda faydalı olabileceğini, \%11'i ise hem öğretmenlik mesleğinde hem de günlük hayatta fayda sağlayacağını ifade etmişlerdir. Pedagojik formasyon derslerini gerekli ve önemli bulmayan öğrencilerden \%53.6'sı öğretmenlik yapmayacağı ya da atanamayacağı için, \%25 ise dersler etkili işlenmediği için gerekli bulmadığını ifade etmişlerdir. Ancak bu derslerin gerekli olduğunu belirten öğrencilerden \%12.6'sı derslerden kaynakl1, \%29'u öğretim elemanlarından kaynaklı, \%4.1'i öğrencilerden kaynaklı ve \%4.1'i ise sistemden kaynaklı problemlerin olduğunu vurgulamışlardır. Bu sonuçlar ele alındığında öğretmen adaylarının çok büyük bir bölümünün pedagojik formasyon derslerinin öneminin farkında oldukları ancak derslerden, öğretim elemanlarından, öğretmen adaylarından ve sistemden kaynaklı problemlerin var olduğunu da belirttikleri görülmektedir. Benzer sorunların 2005 y1lında yapılan "Öğretmen yetiştirmede kalite sorunları çalıştayı (2005, Mart)" nda da ele alındığı görülmektedir. Deniz (1998) stajyer öğretmenlerle yaptığı pedagojik formasyonla ilgili araştırmasında öğretmenlik mesleği için derslerin gerekli ama çeşitli nedenlerle yetersiz olduğunu belirtmiştir. Nartgün'ün (2008) araştırmasında eğitim derslerine gereken önemin verilmediğine yönelik bulgulara rastlanmaktadır. Öğretmen yetiştirmede karşılaşılan problemlerle ilgili çalışmalar ve çözüm arayışları uzun yıllardır devam eden bir süreçtir. Bu çalışma konuları ve ele alınan problemlerin değişerek ve gelişerek 2009 yılında da devam ettiği dolayısıyla çözüme yönelik çalışmaların devam etmesi gerektiği söylenebilir.

Araştırmada kız öğrenciler, erkek öğrencilere göre pedagojik formasyon derslerini istatistiksel olarak anlamlı düzeyde yüksek derecede gerekli ve önemli bulduklarını ifade etmişlerdir. Öztürk, Doğan ve Koç (2005) tarafindan yapılan çalışmada ise cinsiyetler arasında farklılık bulunmadığ 1 ortaya çıkmıştır. Bunun yanında Demirci ve Soran (2001), Saracaloğlu (1991), Tanrı̈ğgen (1997) tarafindan yapılan çalışmalarda kız öğrencilerin mesleğe yönelik tutumlarının daha olumlu olduğu ancak Bulut ve Doğar 
(2006), Çapa ve Çil (2000), Erden (1995), Gürbüztürk ve Genç (2004) tarafindan yapılan çalışmalarda cinsiyetler arasında farklılık bulunmadığı ortaya çıkmıştır. Toplumda öğretmenlik mesleğinin kızlara daha uygun bir meslek olduğu algısı yaygındır. Toplumdaki bu algı kızların mesleğe ve mesleğe yönelik derslere olumlu bakış açısına sahip olmalarını sağlayabileceği düşünülebilir. Bu durum Tanrıöğen (1997) tarafindan da ifade edilmektedir.

Eğitim fakültesi öğrencilerinin pedagojik formasyon derslerini teknik eğitim fakültesi öğrencilerine göre daha çok gerekli ve önemli bulduklarını göstermektedir. Bu bulgu Akpınar ve Özer'in (2003) teknik eğitim fakültesi öğrencileriyle yaptıkları çalışmanın bulguları ile tutarlıdır. Öztürk, Doğan ve Koç (2005) Eğitim fakültesi öğrencilerinin mesleğe yönelik algılarının fen edebiyat fakültesi öğrencilerinden daha yüksek bulmuştur. Eğitim fakültesi öğrencilerinin diğer fakülte öğrencileri ile karşılaştırıldığında öğretmenlik mesleği yapmak amaciyla fakülteye gelmeleri, diğer fakültelerde başka işler yapma olanağının bulunması gibi nedenler bakış açısındaki farklılığın kaynağı olarak görülebilir.

Okuduğu bölümü isteyerek tercih eden öğrencilerin pedagojik formasyon derslerini istemeden tercih eden öğrencilere göre daha çok gerekli ve önemli buldukları görülmektedir. Bu durum Tanrı̈ğen'in (1997) bulgularıyla uyumludur. Mesleği isteyerek tercih eden öğrencilerin öğretmenlik meslek becerilerini kazandıracak derslere yönelik bakış açılarının daha olumlu olması doğaldır.

Atanma oranları yüksek olan bölümlerde okuyan öğrencilerin pedagojik formasyon derslerini atanma oranları düşük olan bölümlerde okuyan öğrencilere göre daha çok gerekli ve önemli buldukları görülmüştür. Öğrencilerin üniversiteye girişte tercihlerini etkileyen en önemli faktör mezunlarının iş bulma olasıllı̆̆ gelir ve bunlardan kaynaklanan toplumsal saygınlıktır. İş bulma olasılığı yüksek olan bölümdeki öğrencilerin mesleğe yönelik ilgi, tutum ve motivasyonları üniversiteye girişte yüksektir. Bu durum öğrenim süresince de devam etmektedir. Karasar da (1981) bir programın saygınlığını etkileyen faktörleri benzer şekilde açıklamaktadır (Akt: Akpınar ve Özer, 2003).

Araştırmaya katılan öğrencilerden alanlarındaki derslere yönelik görüşlerinin sorulduğu ikinci soruya verilen cevaplar üç grupta toplanmıştır. Araştırmaya katılan öğrencilerin \%46.1'i alan derslerinin tamamının gerekli ve önemli olduğunu; \%40.7'si alan derslerinin büyük bir bölümünün gerekli, bazı derslerin gereksiz olduğunu; \%8.9'u ise derslerin çok büyük kısmını gereksiz ya da derslerin çok fazla olduğu için yeterince yararlanamadıklarını ifade etmişlerdir. Üçüncü grup kendi içinde analiz edildiğinde derslerin çok büyük bir kısmının gereksiz olduğunu ifade eden öğrencilerin çalışma grubu 
içindeki oranının \%3.2 olduğu, çalışma grubundaki diğer öğretmen adaylarının bir takım sorunlar olmasına rağmen alan derslerinin büyük bir çoğunluğunun gerekli ve önemli olduğunu ifade ettiği görülmüştür. $\mathrm{Bu}$ da öğretmen adaylarının öğrenim gördükleri bölümdeki alan derslerinin öneminin farkında olduklarını gösterecek niteliktedir. Alan derslerinin önemli görülme oranı pedagojik formasyon derslerinin önemli görülme oranlarından daha fazladır. Bunun nedeni olarak eğitim ve teknik eğitim fakültelerinde okuyan öğrencilerin formasyon dersleri denildiğinde öğretmenlik mesleği dikkatlerini çekerken, eğitim fakültesindeki öğrenciler alan derslerini öğretmenlikle ilişkilendirirken, teknik eğitim fakültesindeki öğrenciler öğretmenlik dışındaki diğer çalışma alanlarını da (fabrika, sanayi gibi) mesleki kapsamda değerlendirerek alan dersleri ile ilişkilendirmektedir. $\mathrm{Bu}$ nedenle alan derslerine yönelik gerekli bulma oranı pedagojik formasyon derslerinden daha yüksek bulunmuş olabilir. Teknik eğitim fakültelerinde alan derslerine ilişkin olumlu tutum ve bakış açısını gösteren farklı çalışmalar bulunmaktadır (Akpınar ve Özer, 2003; Dilmaç, Çıkılı, Işık ve Sungur, 2009).

Araştırmada öğrencilere üçüncü olarak “Öğretmenlik yapmayı düşünüyor musunuz? Cevabınızın nedenini açıklayınız" sorusu sorulmuş ve alınan cevaplar üç ayrı bölümde incelenmiştir. Öğrencilerin verdiği cevaplar ilk olarak öğretmenlik yapmayı düşünüp düşünmeme, ikinci olarak öğretmenlik yapıp yapmayacağının nedenleri, üçüncü olarak öğretmenlik yapıp yapmayacağı ile nedenleri arasındaki ilişki ve demografik faktörlere göre değişimi olarak çözümlenmiştir.

Araştırmaya katılan öğrencilerden \%69'u öğretmenlik yapmayı düşündüğünü, \%17.4'si atanırsa öğretmenlik yapmayı düşündüğünü, \%2.2'si öğretmen olmak istediğini ancak bunun çok zor olduğunu, \%11.4'ü ise öğretmenlik yapmayı düşünmediğini ifade etmiştir. Toplamda öğretmenlik yapmayı düşünenlerin \%88.6 gibi yüksek bir oranda olduğu görülmektedir. Benzer bir sonuç Aksu, Daloğlu, Yıldırım, Kiraz ve Demir (2008) tarafından 51 eğitim fakültesindeki 1. sınıf öğrencileriyle yapılan çalışmada da görülmektedir. $\mathrm{Bu}$ da pedagojik formasyon derslerinin gerekli bulanların oranı (\%90.6) ile paralellik göstermektedir. Araştırmaya katılanlar öğretmen yetiştiren fakültelerde okudukları için öğretmenlik yapmak istemeye yönelik oranın yüksek çıkması doğal bir sonuçtur. Sonradan pedagojik formasyon alan öğrencilerin mesleğe yönelik algıları, mesleği tercih etmeleri ve tutumlarının daha düşük çıktığını vurgulayan araştırmalar vardır (Gürgen ve Deniz, 2003; Öztürk, Doğan ve Koç, 2005).

Eğer atanırsa öğretmenlik yapmayı düşünen ve öğretmenliğe atanmasının zor olduğunu ifade edenlerin toplam oranının \%19.6 olması, öğretmen adaylarının umudunun düşük düzeyde olduğunun bir göstergesidir. 
Diğer öğrenciler kesin ifadelerle belirtmese de atanma oranları düşük olan bölümlerin öğrencilerinin kaygılarının yüksek olduğu gözlenmektedir.

Araştırmaya katılan öğrencilerden kızların erkeklere göre daha çok öğretmen olmak istedikleri, eğitim fakültesi öğrencilerinin öğretmen olmay1 teknik eğitim fakültesi öğrencilerine göre daha çok istedikleri, okuduğu bölümü isteyerek tercih eden öğrencilerin öğretmen olmayı okuduğu bölümü istemeden tercih eden öğrencilere göre daha çok istediği ve atanma oranları yüksek olan bölümlerin öğrencilerinin öğretmen olmayı atanma oranı düşük olan bölümlerin öğrencilerine göre daha çok istediği bulunmuştur. $\mathrm{Bu}$ bulguların ülkenin sosyal ve ekonomik yapısı ile uyumlu olduğu söylenebilir. Toplumda öğretmenliğin kızlar için en uygun mesleklerden biri olarak görülmesi, kızların eğitim fakültelerini daha çok tercih etmelerine, daha yüksek oranda ve daha istekli olarak tercih etmelerine yol açmıştır. Bunun sonucunda da eğitim fakültelerinde kız öğrencilerin oranı artmıştır. Kızılçaoğlu (2003) öğrencilerin mesleğin durumu ile ilgili kaygıları, mesleğe girişteki sınav (KPSS) ve mezuniyet sonrası ciddi bir istihdam sorunu ile karşı karşıya kalmaları, eğitim süreçlerini olumsuz yönde etkilediğini ifade etmektedir. Benzer durumlar bu araştırmada da öğrenciler tarafından sıklıkla ifade edilmiştir. Özellikle nitelikli ve ekonomik açıdan bağımsız olmayı sağlayacak iş bulma kaygısı öğretmen adaylarının motivasyonlarını, tutumlarını ve mesleğe yönelik bakışlarını önemli ölçüde etkilediği görülmektedir. Bu durum öğrencilerin bölüm tercihlerinde etkili olmaktadır. Okuduğu bölümü bilerek, isteyerek tercih edenlerin bu mesleği yapma iradesini daha yüksek oranda belirtmeleri devam eden bir kararlılığın doğal sonucudur.

Araştırmada genel olarak ders programları, derslerin işleniş biçimi, öğretim elemanlarının nitelikleri, öğrencilerin KPSS sınavı ve istihdam ile ilgili kaygıları ön plana çıkmıştır. Çalışma grubu olarak 1997 programının son mezun adayları, yan alan derslerinden dolayı alan dışı dersler almak zorunda kaldıklarını, buna karşın alanla ilgili derslerin nasıl öğretileceği doğrultusundaki uygulamalı derslerin yetersiz olduğunu, 2006 programının bu açıdan daha olumlu olduğunu ifade etmişlerdir. 2006 programıla eğitim alan öğrencilerin görüşlerinin de araştırılması ve buna yönelik dönütler alınması durum tespiti açısından önemli görülmektedir. Eğitim fakültesi programlarının YÖK tarafından belirlenmiş olması ve fazla bir esnekliğin olmaması fakültelerin karşılaştıkları sorunlara kısa sürede tepki verme şansını ortadan kaldırmaktadır. Bunun için eğitim fakültesi programlarında belli bir oranda esneklik hakkının fakültelere tanınması bu kurumlara kendi olanaklarını da göz önünde bulundurarak çözüm üretebilme şansını tanıyacaktır. 
Teknik eğitim fakültesi öğrencilerinin azımsanamayacak bir bölümünün öğretmen olmak istemedikleri, isteyenlerin ise atanma şansının az olduğu istatistiklerde görünmektedir. Bu haliyle teknik eğitim fakültelerinin eğitim kısmı anlamını yitirmektedir. Bu ve benzer araştırmaların sonuçları teknik eğitim fakültelerinde bir değişiklik ihtiyacını göstermektedir. 2009 yılında bu fakültelerin yapısı, işlevi, programı ve ismi değiştirilmiştir. Yeni yapılanmayla ilgili durumun izlenmesini sağlayacak çalışmaların yapılması yararlı olacaktır.

Öğretmen yetiştiren fakültelerdeki öğrenciler derslerin planlanması, işleniş̧i ve ölçme değerlendirme gibi açllardan öğretim elemanlarının kendilerine rol model olmalarını, sadece teorik bilgileri vermek değil bunların uygulanışı ile ilgili model davranışlar sergilemelerini ve üst düzeyde akademik yetkinlik sahibi olmalarını beklemektedirler. Öğrencilerin öğretim elemanlarının nitelikleriyle ilgili ifade ettikleri problemler öğretim elemanı başına düşen öğrenci, ders ve akademik çalışma sayısı ile ilişkilendirilebilir. Bu noktada öncelikli olarak öğretim üyelerinin iș yükünün hafifletilmesi için yeterli sayıda kadro sağlanması ve akademik olarak kendilerini daha iyi yetiştirilebilmeleri için gerekli olanakların sağlanması önerilmektedir.

Araştırma sonuçları bölümlerine isteyerek gelen öğrencilerin öğretmenlik mesleğini daha çok benimsediğini ve öğretmen olma isteklerinin daha yüksek olduğunu göstermektedir. Bu da üniversiteye girişte bilinçli tercih yapmanın ve bunu yapabilmek için rehberlik hizmetlerinin önemini bir kez daha ortaya koymaktadır. Yüksek öğretime girecek olan öğrencilere ve onların velilerine mesleki tercih konusunda doğru ve yeterli rehberlik hizmetlerinin arttırılması yararlı olacaktır.

Araştırma sonucunda öğretmen adaylarının en çok vurguladıkları problem KPSS sinavi ve istihdam sorunudur. $\mathrm{Bu}$ problemler öğretmen adaylarında yüksek düzeyde kaygıya yol açmaktadır. Bu kaygılar eğitimöğretim sürecine olumsuz yansımaktadır. Özellikle eğitim fakültesinde okuyan öğrencilerin aldıkları eğitim, öğretmen olmaya yönelik olduğundan öğrencilerin gelecekteki iş beklentileri de öğretmen olmaya odaklıdır. $\mathrm{Bu}$ nedenle birçok bölümdeki atanma oranlarının düşük olması bu bölümde okuyan öğrencilerdeki kaygıyı arttırmakta, verimliliği ise azaltmaktadır. Bu sorunun çözümüne yönelik olarak öğretmen ihtiyaçlarının gerçekçi olarak belirlenmesi ve eğitim fakültelerinin sayılarının ve kontenjanlarının bu doğrultuda planlanması daha nitelikli öğretmen yetiştirilmesi ve kaynakların etkili kullanımı açısından yararlı olacaktır. 


\section{KAYNAKLAR}

Akpınar, B. ve Özer, B. (2003). Teknik eğitim fakültesi otomotiv programlarının öğrenci görüşlerine göre değerlendirilmesi. Teknoloji Dergisi, 6(3-4), 95-106.

Aksu, M., Daloğlu, A., Yıldırım, S., Kiraz, E. ve Demir, C.E. (2008). Geleceğin öğretmenleri kimler: Eğitim fakülteleri öğrenci profili. İlköğretmen Ĕ̈itimci Dergisi, 16, 44-48.

Archambault, L. ve Crippen, K. (2009). Examining TPACK among K-12 online distance educators in the United States. Contemporary Issues in Technology and Teacher Education, 9(1). http://www.citejournal.org/vol9/iss1/general/article2.cfm adresinden 14.02.2011 tarihinde erişilmiştir.

Bulut, H. ve Doğar, Ç. (2006). Öğretmen adaylarının öğretmenlik mesleğine karşı tutumlarının incelenmesi. Erzincan Eğitim Fakültesi Dergisi, 8(1), 13-27.

Çapa, Y. ve Çil, N. (2000). Öğretmen adaylarının öğretmenlik mesleğine yönelik tutumlarının farklı değişkenler açısından incelenmesi. Hacettepe Üniversitesi Ĕgitim Fakültesi Dergisi, 18, 69-73.

Çelikkaya, H. (2006). Ĕ̈itim bilimlerine giriş (eğitimcilik ve öğretmenlik). İstanbul: Alfa basım yayın dağıtım.

Demirci, C. ve Soran, H. (2001, Haziran). Hacettepe üniversitesi eğitim fakültesi fen bilimleri bölümü 1. ve 4. sınıf öğrencilerin öğretmenlik mesleğine yönelik tutumlarının öğrencilere ait bazı değișkenler açısından belirlenmesi. X. Ulusal Ĕgitim Bilimleri Kongresi Bildirileri, 1, 424-439.

Deniz, S. (1998, Eylül). Farklı branşlardan sınıf öğretmenliğine atanan öğretmen adaylarının pedagojik formasyon programlarına ilişkin görüşleri. VII. Ulusal Eğitim Bilimleri Kongresi, Konya.

Dilmaç, B., Çıkılı, Y., Işık, H. ve Sungur, C. (2009). Teknik öğretmen adaylarının öğretmenlik mesleklerine ilişkin tutumlarının yordayıcısı olarak mesleki benlik saygısı. Selçuk Üniversitesi Teknik Bilimler Meslek Yüksekokulu Teknik-Online Dergi, 8(2), 34-50.

Ekici, G. (2008). Öğretmen adaylarının öğretmenlik meslek bilgisi derslerine yönelik tutumları ile öğrenme biçimlerinin değerlendirilmesi. Yüzüncü Yll Üniversitesi, Ë̆itim Fakültesi Dergisi. V(I), 111-132. http://efdergi.yyu.edu.tr adresinden 20.11.2009 tarihinde erişilmiştir.

Erden, M. (1995). Öğretmen adaylarının öğretmenlik sertifikası derslerine yönelik tutumları. Hacettepe Üniversitesi Eğitim Fakültesi Dergisi, 11, 99-104. 
Gökçe, E. (2001, Haziran). Üniversitelerin sınıf öğretmenliği programlarına devam eden öğrencilerin öğretmenlik mesleğine ilişkin görüşleri. $X$. Ulusal Eğitim Bilimleri Kongresi Bildirileri, Cilt 1, 1432-1441.

Görgen, İ. ve Deniz, S. (2003). Orta öğretim branş öğretmenliği öğretmen adaylarının öğretmenlik sertifikası programına yönelik görüşleri. Milli Eğitim Dergisi, 158. http://yayim.meb.gov.tr/dergiler/158/gorgen.htm adresinden 24.09.2009 tarihinde erişilmiştir.

Gürbüztürk, O. ve Genç, S.Z. (2004). Öğretmen adaylarının öğretmenlik mesleğine ilişkin görüşleri. İnönü Üniversitesi Eğitim Fakültesi Dergisi, 5. http://www.pegem.net/akademi/3-8231-Ogretmen-AdaylarininOgretmenlik-Meslegine-Iliskin-Gorusleri.aspx adresinden 20.11.2009 tarihinde erişilmiştir

Harris, J.B., Mishra, P. ve Koehler, M.J. (2007). Teachers' technological pedagogical content knowledge: Curriculum-based technology integration reframed. Içinde Annual Meeting of the American Educational Research Association, Chicago, IL.

Karasar, N. (1995). Bilimsel araştırma yöntemi, kavramlar, ilkeler. Ankara: 3A Araştırma Eğitim Danışmanlık Ltd.

Kılıç, A. (2007). Sınıf öğretmeni yetiştirme programında yer alan derslerin öğrenilme düzeyleri. Elektronik Sosyal Bilimler Dergisi, 6(19), 136145.

Kızılçaoğlu, A. (2003). Necatibey eğitim fakültesi sosyal bilgiler öğretmeni adaylarının profili. Ballkesir Üniversitesi Sosyal Bilimler Enstitüsü Dergisi, 6(10), 87-106.

Koehler, M.J. ve Mishra, P. (2009). What is technological pedagogical content knowledge? Contemporary Issues in Technology and Teacher Education, 9(1), 60-70.

Mishra, P. ve Koehler, M.J. (2007). Technological Pedagogical Content Knowledge (TPCK): Confronting the Wicked Problems of Teaching with Technology. In C. Crawford et al. (Eds.), Proceedings of Society for Information Technology and Teacher Education International Conference 2007 (pp. 2214-2226). Chesapeake, VA: AACE.

Mishra, P. ve Koehler, M.J. (2006). Technological pedagogical content knowledge: A framework for teacher knowledge. The Teachers College Record, 108(6), 1017-1054.

Nartgün, Ş.S. (2008). Aday öğretmenlerin gözüyle Milli Eğitim Bakanlığına bağlı eğitim kurumlarına öğretmen atama esasları. Abant İzzet Baysal Üniversitesi Ĕ̈itim Fakültesi Dergisi, 8(2), 47-58.

ÖYKSÇ, (2005, Mart). Ankara üniversitesi eğitim bilimleri fakültesi 40.yıl; ögretmen yetiştirmede kalite sorunları çalıştayı. Ankara. 
http://calistay.education.ankara.edu.tr/UserFiles/File/calistay2005.pdf adresinden 18.11.2009 tarihinde erişilmiştir.

Öztürk, B., Doğan, O. ve Koç, G. (2005). Eğitim fakültesi öğrencileri ile fen-edebiyat fakültesi mezunlarının öğretmenlik mesleğine yönelik algılarının karşılaştırılması (gazi üniversitesi örneği). Türk Eğitim Bilimleri Dergisi, 1(3), 1-22.

Saracaloğlu, A.S. (1991, Kasım). Fen ve edebiyat fakülteleri öğrencilerinin ögretmenlik mesleğine yönelik tutumları. 1. Ulusal Eğitim Kongresi Bildirileri. 565-569.

Semerci, N. (2004, Temmuz). Öğrenci görüşlerine göre sınıf öğretmenliği derslerinin işleyişi (firat üniversitesi örneği). XIII. Ulusal Eğitim Bilimleri Kurultayl, Malatya. http://www.pegema.net/dosya/dokuman/190.pdf adresinden 24.09.2009 tarihinde erişilmiştir.

Shulman, L.S. (1986). Those Who Understand: Knowledge Growth in Teaching. Educational Researcher, 15(2), 4-14.

Shulman, L.S. (1987). Knowledge and Teaching: Foundations of the New Reform. Harvard Educational Review, 57(1), 1-22.

Tanrıöğen, A. (1997). Buca eğitim fakültesi öğrencilerinin öğretmenlik mesleğine yönelik tutumları. PAÜ Ĕ̈itim Fakültesi Dergisi, 3, 55-67.

TUIK (2009). Türkiye İstatistik Kurumu işsizlik oranları http://www.tuik.gov.tr/PreHaberBultenleri.do?id=4146\&tb_id=3 adresinden 18.11.2009 tarihinde erişilmiştir.

Yıldırım, A. ve Şimşek, H. (2004). Sosyal bilimlerde nitel araştırma yöntemleri. Ankara: Seçkin Yayıncılık.

YÖK (2007). T.C. Yükseköğretim Kurulu: Öğretmen yetiştirme ve eğitim fakülteleri (1982-2007). Ankara: Meteksan. 


\section{EK-1}

2004-2009 Yılları Arasındaki Bölümlere Göre Toplam Başvuru Sayıları, Atanma Sayıları ve Atanma Oranları

\begin{tabular}{|l|c|c|c|}
\hline \multirow{2}{*}{ Bölümler } & \multicolumn{3}{|l|}{ Son alt1 yıldaki durum } \\
\cline { 2 - 4 } & Başvuru & Atanan & Atanma Oran1 \\
\hline Bilgisayar & 16919 & 10376 & 61.32 \\
\hline Fen bilgisi & 51314 & 7634 & 14.87 \\
\hline Okul öncesi & 60112 & 8836 & 14.69 \\
\hline Rehberlik & 9025 & 5198 & 57.59 \\
\hline Sinıf & 155708 & 45105 & 28.96 \\
\hline Sosyal & 56718 & 5027 & 8.86 \\
\hline Otomotiv & 5924 & 30 & 0.50 \\
\hline Yap1 & 4432 & 2 & 0.05 \\
\hline Elektronik & 4561 & 313 & 6.86 \\
\hline
\end{tabular}

\section{EK-2}

Yıllara ve Bölümlere Göre Başvuru ve Atanma Sayıları

\begin{tabular}{|c|c|c|c|c|c|c|c|c|c|c|c|c|}
\hline \multirow[t]{2}{*}{ Bölümler } & \multirow{2}{*}{$\begin{array}{c}2009 \\
\text { Başv. }\end{array}$} & \multirow{2}{*}{\begin{tabular}{|c|}
2008 \\
Atama
\end{tabular}} & \multirow{2}{*}{$\begin{array}{l}2007 \\
\text { Bașv. }\end{array}$} & \multirow{2}{*}{\begin{tabular}{|c|}
2006 \\
Atama
\end{tabular}} & \multirow{2}{*}{$\begin{array}{c}2005 \\
\text { Başv. }\end{array}$} & \multirow{2}{*}{\begin{tabular}{|c|}
2004 \\
Atama
\end{tabular}} & \multirow[b]{2}{*}{ Basv. } & \multirow[b]{2}{*}{ Atama } & \multirow[b]{2}{*}{ Basv. } & \multirow[b]{2}{*}{ Atama } & \multirow[b]{2}{*}{ Basv. } & \multirow[b]{2}{*}{ Atama } \\
\hline & & & & & & & & & & & & \\
\hline Bilgisayar & 2817 & 645 & 4115 & 3393 & 3145 & 1707 & 2916 & 2020 & 2039 & 1088 & 1887 & 1523 \\
\hline $\begin{array}{l}\text { Fen } \\
\text { bilgisi }\end{array}$ & 4043 & 684 & 12350 & 2761 & 10766 & 1445 & 9389 & 1346 & 8266 & 1049 & 6500 & 349 \\
\hline $\begin{array}{l}\text { Okul } \\
\text { öncesi }\end{array}$ & 4494 & 739 & 18406 & 2245 & 14114 & 1810 & 11637 & 1550 & 7194 & 1492 & 4267 & 1000 \\
\hline Rehberlik & 1455 & 350 & 2348 & 1558 & 1396 & 907 & 1439 & 752 & 1067 & 361 & 1320 & 1270 \\
\hline Sinif & 17965 & 3605 & 32313 & 15674 & 30089 & 5516 & 27382 & 12879 & 27086 & 4080 & 20873 & 3351 \\
\hline Sosyal & 2472 & 345 & 14418 & 1246 & 12442 & 1178 & 11021 & 956 & 9372 & 902 & 6993 & 400 \\
\hline Otomotiv & 900 & 30 & 1112 & 0 & 929 & 0 & 1242 & 0 & 732 & 0 & 1009 & 0 \\
\hline Yap1 & 850 & 0 & 872 & 0 & 702 & 0 & 997 & 0 & 773 & 0 & 238 & 2 \\
\hline Elektronik & 840 & 21 & 834 & 30 & 818 & 10 & 675 & 50 & 564 & 92 & 830 & 110 \\
\hline
\end{tabular}

* Öğretmenliğe atanan kişilerin sayısı Milli Eğitim Bakanlığı personel dairesi başkanlığının http://personel.meb.gov.tr/sayfa_goster.asp?ID=207 adresinden elde edilmiştir.

Öğretmenlik bölümlerine kimlerin başvurabildiği verileri;

http://personel.meb.gov.tr/upload/Kimler_ogretmen_olur.pdf adresinden alınmıştır.

Öğretmenliğe başvuru verileri;

http://osym.gov.tr/BelgeGoster.aspx?F6E10F8892433CFF8FE9074FF19B00056AD

B17BCA15FC4FC adresinden alınmıştır. 
